NASA Technical Memorandum 104533

AIAA-91-2227

\title{
Medium Power Hydrogen Arcjet Performance
}

Francis M. Curran, S. Ray Bullock, Thomas W. Haag, Charles J. Sarmiento, and John M. Sankovic Lewis Research Center Cleveland, Ohio

Prepared for the 27th Joint Propulsion Conference cosponsored by the AIAA, SAE, ASME, and ASEE Sacramento, California, June 24-27, 1991

\section{NRSA}




\title{
MEDIUM POWER HYDROGEN ARCJET PERFORMANCE
}

\author{
Francis M. Curran*, S. Ray Bullock, Thomas W. Haag*, \\ Charles J. Sarmiento, and John M. Sankovic* \\ NASA Lewis Research Center \\ Cleveland, Ohio
}

\begin{abstract}
An experimental investigation was performed to evaluate hydrogen arcjet operating characteristics in the range of 1 to $4 \mathrm{~kW}$. A series of nozzles were operated in modular laboratory thrusters to examine the effects of geometric parameters such as constrictor diameter and nozzle divergence angle. Each nozzle was tested over a range of current and mass flow rates to explore stability and performance. In the range of mass flow rates and power levels tested, specific impulse values between 650 and $1250 \mathrm{sec}$ were obtained at efficiencies between 30 and 40 percent. The performance of the two larger half angle $\left(20^{\circ}, 15^{\circ}\right)$ nozzles was similar for each of the two constrictor diameters tested. The nozzles with the smallest half angle $\left(10^{\circ}\right)$ were difficult to operate. A restrike mode of operation was identified and described. Damage in the form of melting was observed in the constrictor region of all of the nozzle inserts tested. Arcjet ignition was also difficult in many tests and a glow discharge mode that prevents starting was identified.
\end{abstract}

\section{Introduction}

Hydrogen arcjets were first considered for both primary and auxiliary space propulsion missions in the late-1950's. At that time, the availability of lightweight, nuclear-electric power generation systems was anticipated ${ }^{1}$ and the major focus of the government-sponsored effort was directed toward the development of $30 \mathrm{~kW}$ engines for orbit transfer. The Avco Corporation developed a radiation-cooled, constricted arc design that was successfully lifetested for one month $(732 \mathrm{hr})$ at the $1000 \mathrm{sec}$ specific impulse level..$^{2,3} \mathrm{~A}$ regeneratively-cooled, $30 \mathrm{~kW}$, hydrogen thruster that demonstrated efficiencies above 50 percent at $1000 \mathrm{sec}$ was built by the Giannini Scientific corporation and this device was also successfully lifetested. ${ }^{4,5}$ During the same period, the Plasmadyne Corporation developed both 1 and $2 \mathrm{~kW}$ hydrogen thrusters of the radiation-cooled, constricted arc design for satellite stationkeeping and orbital maneuvering. ${ }^{6-8}$ The $1 \mathrm{~kW}$ unit was designed specifically for the Space Electric Rocket Test I (SERT I). Design problems severely limited the operational life of this device and the system was never flown. Some parametric optimization was performed under the $2 \mathrm{~kW}$ program and device was successfully tested for $150 \mathrm{hr}$. In the early 1960 's, it was realized that the initial estimates of the nuclear-electric power plant specific mass were overly optimistic and the high power arcjet program was discontinued. Long term storage of hydrogen on orbit was also found to be prohibitive due to issues related to hydrogen boil off and, after brief and relatively unsuccessful attempts were made to run the low power arcjet on alternate propellants, this effort was also terminated in the same time frame. A comprehensive review of these early programs was given by Wallner and Czika in $1965 .^{9}$

Recently, low power (1 to $2 \mathrm{~kW}$ class) arcjets have been reevaluated for application to the north-south stationkeeping for geosynchronous communications satellites. To maintain compatibility with existing satellite subsystems and mission profiles, current programs have focused on arcjet systems that will operate at power levels between 1 and $2 \mathrm{~kW}$ using hydrazine decomposition products as the propellant. Stable, reliable, long-term operation under these conditions at specific impulse levels in the 450 to $550 \mathrm{sec}$ range have been demonstrated in the laboratory. ${ }^{10-13}$ A flight-type $1.4 \mathrm{~kW}$ system has been fabricated and life and performance tested. ${ }^{14,15}$ In addition, the effects of plume impacts have been investigated ${ }^{16,17}$ and a system integration demonstration has been performed. ${ }^{18,19}$

In addition to the low power programs, high power arcjets are also being reconsidered for primary propulsion. A significant effort has been directed toward the development of a $26 \mathrm{~kW}$ ammonia arcjet that is scheduled for a near-term 
flight test. ${ }^{20}$ A hydrogen arcjet program has also recently been initiated. Most of this effort has been directed toward 10 to $30 \mathrm{~kW}$ devices for orbit transfer missions in which long term cryogenic hydrogen storage is not essential. Certain applications, including a potential near-term flight demonstration, may require lower power devices. Aside from the above-mentioned programs at the Plasmadyne Corporation, little work on low to medium power ( 1 to $5 \mathrm{~kW}$ ) hydrogen arcjets has been reported.

The objectives of the experimental study described in this report were to obtain a preliminary assessment of the operating characteristics of hydrogen arcjets tested at power levels between 1 and $5 \mathrm{~kW}$ and to determine issues important to the further development of these devices. A series of nozzle inserts were used to examine the effects of anode geometry in the standard, constricted arc design. Arcjet ignition and transition to steady state operation was examined and modal behavior observed during operation is discussed. The effect of facility background pressure on arcjet performance was also studied.

\section{Apparatus}

\section{Arcjet Thruster}

A simplified cross-sectional schematic of the arcjet thruster used in this study is shown in figure 1. A cutaway of the critical region of the nozzle is called out in the figure. The thruster was modular and similar to thrusters used in many recent tests. ${ }^{11,13}$ For the parametric test series performed in this study, two sets of three 2 percent thoriated tungsten nozzle/anode inserts were fabricated. The half angle in the converging section of each nozzle insert was $30^{\circ}$. The half angle in the diverging section of the inserts was varied within each set. For the parametric analyses, half angles of $10^{\circ}, 15^{\circ}$, and $20^{\circ}$ were chosen. Between sets, the constrictor diameter was varied. The nominal values of the constrictor diameters for sets 1 and 2 were 0.56 and $0.76 \mathrm{~mm}$, respectively. The actual values measured before and after testing are shown in table I. Constrictor lengths were nominally $0.25 \mathrm{~mm}$. Separate anode housings were used for each set of nozzle inserts. These housings were made of titaniated-zirconiated molybdenum (TZM). Each housing was nominally $76 \mathrm{~mm}$ in length and had an inner diameter of $19 \mathrm{~mm}$. At a location $3.2 \mathrm{~mm}$ from the rear face of the anode housing, the inner diameter expanded to $25.4 \mathrm{~mm}$ to accomodate the rear insulator. The housing used with the small $(0.6 \mathrm{~mm})$ constrictor anode inserts was $39 \mathrm{~mm}$ in diameter and the inserts were designed to match a $5^{\circ}$ angle tapered hole machined into the front face of the anode housing. For the large constrictor $(0.8 \mathrm{~mm})$ inserts, a housing $32 \mathrm{~mm}$ in diameter and a taper angle of $2.5^{\circ}$ was used. Prior to assembly of the device, the nozzle inserts were lapped into the anode housing in order to minimize leakage. A separate front insulator made of high purity boron nitride was used for each set of inserts. These insulators were $19 \mathrm{~mm}$ in diameter to match the inner diameter of the anode housings and approximately $50 \mathrm{~mm}$ in length. Lengths were adjusted slightly to match individual assembly tolerances in each arcjet. Rectangular grooves were cut along the length of the insulator exterior to guide propellant flow between the insulator and the stainless steel anode housing. A $3.2 \mathrm{~mm}$ hole was drilled through the center of the insulator to center the cathode. The diameter of this hole was slightly enlarged at the cathode tip end after an interaction between the cathode and the boron nitride was noticed which prevented the front insulator from moving freely.

The remainder of the parts used in the arcjet assemblies were common to both thrusters. A 2 percent thoriated tungsten rod, $3.2 \mathrm{~mm}$ in diameter and $190 \mathrm{~mm}$ in length, was used as the cathode. The tip of the cathode was conical with a $30^{\circ}$ half angle to match the converging side of the nozzle. A propellant injection disk made from TZM provided tangential swirl of the propellant in the chamber upstream of the constrictor to stabilize the arc. This disk had a center bore $6.4 \mathrm{~mm}$ in diameter and the twin injection ports were nominally $0.51 \mathrm{~mm}$ in diameter.

To set the arc gap, or cathode to anode spacing, the cathode was moved forward until it contacted the anode and then withdrawn $0.58 \mathrm{~mm}$.

The rear insulator and the compression plunger were made from high purity boron nitride. A modified stainless steel compression fitting was used to insert the cathode through the rear insulator of the thruster and clamp it in place. A threaded, center-drilled holding bolt inserted into the insulator in order to secure this fitting. The rear insulator also contained an inconel spring and a boron nitride compression plunger. Two stainless steel plates were used to hold the rear insulator and the anode housing together. Clearances were adjusted so that the spring was in compression when the arcjet was assembled. Propellant was fed into the arcjet through a modified stainless steel compression fitting located on the side of the rear insulator. This fitting was held by a side-tapped, centerdrilled stainless steel ring in the center of the rear insulator. Both the cathode and a ceramic sleeve fit through this ring, with the latter provided for cathode/propellant line isolation.

Flexible graphite gaskets were used at critical surfaces throughout the arcjet and a shallow spiral groove was machined into the surface at the rear of each anode housing to improve the sealing capability in this region.

\section{Vacuum Facility}

A majority of the tests described in this report were performed in a $0.91 \mathrm{~m}$ diameter by $0.91 \mathrm{~m}$ cylindrical test section attached to a $0.91 \mathrm{~m}$ gate valve. This gate valve was mounted on the side of a cylindrical vacuum facility that was $4.5 \mathrm{~m}$ in diameter and $18.3 \mathrm{~m}$ long. This facility was pumped by 20 oil diffusion pumps rated at $30000 \mathrm{lps}$. Because watercooled baffles were used, the actual pumping speed for each 
of these pumps was more on the order of $15000 \mathrm{lps}$. The diffusion pumps were backed by four $1450 \mathrm{lps}$ rotary blowers and four $240 \mathrm{lps}$ mechanical roughing pumps. Under normal operating conditions, the tank pressure was on the order of $0.02 \mathrm{~Pa}$ with full propellant flow.

\section{Thrust Measurements}

A calibrated flexure-type thrust stand mounted in the test section was used to obtain thrust measurements. This stand was also used in testing of a high power hydrogen arcjet, ${ }^{21}$ and, because of this, the sensitivity obtained in testing was slightly below what would have been realized had the stand been optimized for these tests alone.

\section{PropeIIant Supply System}

Ultra-high purity hydrogen gas was supplied from standard cylinders in all tests. Thermal conductivity-type mass flow controllers were used to meter the gas. These controllers were calibrated periodically using a volumetric method.

\section{Power Processing and Measurement}

Laboratory model pulse-width modulated power processing units (PPU) were used in the course of testing. These have been described in detail elsewhere. ${ }^{22,23}$ Under some conditions, the voltage required to operate the arcjet was higher than the maximum rated voltage output of the standard supplies. In order to test at these higher voltage operating points, the output transformers on two of the standard supplies were modified to allow operation at higher voltage.

A $0.1 \mathrm{~m} \Omega \mathrm{ohm}$ current shunt was used to monitor the current and an isolated digital multimeter was used to monitor the signal from the shunt. Arc voltage was also monitored with an isolated digital multimeter connected at the feedthroughs to the port and these dc measurements were used in all calculations of arcjet power dissipation. At times, both analog and digital oscilloscopes were used to observe the dynamic arc characteristics.

\section{Experimental Procedure}

\section{Burn-in/Test Sequence}

Arcjets commonly require a burn-in period before stable, consistent operation is obtained. This is due to changes that take place in the critical electrode region near the cathode tip before a steady state operating configuration is attained. At the outset of testing, the arcjet was assembled with a freshly tipped cathode. This thruster was operated until a relatively steady state operating condition was attained before any performance measurements were taken. This cathode was then used in all subsequent testing. For each nozzle test sequence, the arcjet was reassembled and then run at a set operating point for at least $30 \mathrm{~min}$ before performance measurements were taken. This period was sufficient to bring the arcjet to a near steady state condition in which the operating characteristics were not changing significantly with time.

The preliminary test sequence called for each nozzle to be tested at $1.12 \times 10^{-5}, 1.61 \times 10^{-5}$, and $2.12 \times 10^{-5} \mathrm{~kg} / \mathrm{s}$ over a range of powers between 1 and $5 \mathrm{~kW}$. A maximum anode housing temperature limit was set arbitrarily at $1450^{\circ} \mathrm{C}$ based on previous experience and this was loosely adhered to throughout testing.

Care was taken to account for all drifts in the thrust measurement. To obtain a performance point, the arcjet was started and operated until thermal equilibrium was reached. The arcjet was then shut off and the baseline reading obtained at that point was used for data reduction. This practice minimized thrust measurement uncertainty due to long term zero drift.

\section{Results and Discussion}

The objectives of this experimental study were to obtain a preliminary assessment of the operating characteristics of hydrogen arcjets operated at power levels between 1 and $5 \mathrm{~kW}$ and to determine issues important to the further development of these devices. In the parametric studies performed in the 1960 's, a $20^{\circ}$ nozzle half-angle was found to be optimal for hydrogen arcjets run at the $2 \mathrm{~kW}$ level. ${ }^{8}$ Murch, et al., later showed that this half angle was optimal for low Reynolds number nozzle flows. ${ }^{24}$ At the $30 \mathrm{~kW}$ level, small nozzle half-angles $\left(7^{\circ}\right)$ were used in constrictedarc designs tested by $\mathrm{Avco}^{2,3}$ while the regenerative design developed by the Giannini Scientific Corp. incorporated a nozzle with a half angle of $15^{\circ} .4,5$ Small $(<60)$ nozzle area ratios were also used in all of the early thruster programs. $^{3-8}$ A recent study of the effects of area ratio on low power arcjet performance showed that for small arcjets run on simulated hydrazine decomposition products, performance increased as the area ratio was increased up to about 300 , the highest value tested. ${ }^{25}$ The nozzle inserts used in this study were machined to provide nearly the highest possible area ratios given their geometries and a $20^{\circ}$ nozzle half-angle was chosen as the baseline for comparison.

\section{General Comments}

Data taken with each of the nozzle inserts are shown in tables II to VII. Nozzle insert 1 was operated over the widest range of test conditions and data taken with this insert will be used to illustrate general operating trends and characteristics. Figure 2 shows plots of the current-voltage characteristics obtained with this insert at various mass flow rates. The data shows more variation in repeated points in some places than has typically been observed in this 
laboratory in tests of low power arcjets run on hydrogen/ nitrogen mixtures, albeit over much narrower ranges of specific power. Two likely causes for these variations were documented. First and most obvious, changes in the electrode configuration were observed over the course of testing. Damage in the form of melting was observed in the constrictor regions of the anodes and in some cases the arc gap was found to have increased by up to $0.13 \mathrm{~mm}$ during the course of testing. Second, observation of the dynamic arc characteristics revealed distinct modal behavior. Both of these phenomena will be discussed in following sections. It should be noted that these variations did not seem to impact overall arcjet performance except at the lowest mass flow rate where the variations became the most severe. As noted previously, the thrust stand used in these tests had been optimized for a 10 to $30 \mathrm{~kW}$ engine and so some scatter in the thrust measurements due to the subsequent loss in resolution was expected. In order to examine the repeatability of the data, a number of test points were repeated in each sequence of tests. An example of this is shown in rows 8 to 12 of table II. Here, a low current, medium mass flow rate test point was repeated five times at power levels between 1 and $1.6 \mathrm{~kW}$. This point was chosen because the measured thrust levels at this point were relatively low compared to those obtained over the entire test range. Uncertainties due to lack of resolution will be largest at lower thrust levels. From the data, the standard deviation in the specific impulse and the efficiency were found to be approximately $11 \mathrm{~s}$ and 0.01 , respectively. Another example is shown in rows 19 to 22 of table II. Here, similar test points were repeated in testing performed in three different test periods. Between these test periods, the thruster was removed from the facility and disassembled for use in other testing. The standard deviation in specific impulse and efficiency in the four points taken were $10 \mathrm{~s}$ and 0.005 , respectively.

\section{Post-Test Component Conditions}

Post-test analyses of the nozzle inserts revealed that damage in the form of erosion due to melting had occured in the constrictor regions. An example of this is shown in figure 3. Figures 3(a) and (b) show the upstream and downstream ends of the constrictor from nozzle insert 1 . This insert originally had a smooth finish and a constrictor diameter of $0.61 \mathrm{~mm}$. In figure 3(a), arc tracks are clearly visible and erosion in the form of melting is obvious. Melting at the opposite, downstream, end of the constrictor is clearly evident in figure 3(b). Figure 3(c) provides a view along the contrictor showing the condition in this region. By the conclusion of testing, the measured diameter of the constrictor had increased from $0.61 \mathrm{~mm}$ to approximately $0.70 \mathrm{~mm}$. Post test measurements showed that the arc gap increased by as much as $0.13 \mathrm{~mm}$ in some cases. While these changes appear to be quite extensive, in fact, very little change was noticed in the actual performance of the thrusters and this will be discussed in the next section.

\section{Arcjet Performance}

Nozzle insert 1 was run at all three mass flow rates and over a wide range of power levels. Specific impulse and efficiency are shown plotted versus specific power in figures 4(a) and (b), respectively. Efficiency was calculated as shown in Appendix A. From figure 4(a), it can be seen that at both the upper and middle mass flow rates the thruster was throttled over a range of specific power greater than 4 to 1 . At both of these flow rates stable and consistent operation was obtained. Specific impulses in excess of $1200 \mathrm{sec}$ were attained. The clustered data points indicate that the data were quite repeatable. Figures 4(a) and (b) shows that at the higher mass flow rates, thruster efficiencies gradually declined from values between 37 and 39 percent at specific impulse levels below $850 \mathrm{sec}$ to values between 32 and 36 percent at the highest value of specific impulse. At the low end of the specific impulse range, the efficiency was not dependent on mass flow rate for the two higher mass flow rates tested. As specific impulse increased, however, operation at the highest mass flow rate produced the highest efficiency levels. While the statistical significance between any chosen data points is questionable, the general trend is similar to one observed in previous tests of similar thrusters operated on hydrogen/ nitrogen mixtures. In those tests, specific impulse (and also efficiency) was found to increase with increasing mass flow rate at a constant specific power above a certain lower limit. ${ }^{22,27}$ Recent calorimetric experiments suggest that this may be attributable to an increase in anode fall voltage in addition to the reduced heat transfer rate expected as mass flow rate is decreased. ${ }^{28}$ Also consistent with this hypothesis was the fact that at a fixed specific power level, measurements taken with an optical pyrometer indicated that the anode housing temperature increased as mass flow rate was decreased.

At the lower mass flow rate, arcjet stability decreased markedly. This was most clearly evidenced by the fluctuations observed in the thruster operating voltage, as measured by the dc multimeter, at repeated data points. The data in table II show that at the higher mass flow rates the variation in arcjet voltage at fixed current was typically less than $4 \mathrm{~V}$ over the course of testing. At the lower mass flow rate the observed variation in voltage was much larger, more than $14 \mathrm{~V}$ as shown in figure 2, for the test points repeated during testing. The data also indicate that superior performance was obtained when the arcjet operated in the high voltage mode. This can be seen by comparing the efficiency data presented in figure 4(b) with the current/ voltage characteristics shown in figure 3 . Here, the two lower voltage mode points obtained at the lowest mass flow rate correspond to the low efficiency points shown in figure 4(b).

The effect of nozzle angle on performance is shown in figure 5. In the figure, specific impulse is plotted versus specific power for both of the sets of nozzles. For clarity, figure 5(a) shows the data taken with the nozzle inserts from set 2 (larger constrictor diameter) at only the highest mass 
flow rate tested and figure 5(b) shows the data taken at the middle mass flow rate with the nozzle inserts from set 1 (smaller constrictor diameter). In the tests, operation with both the $15^{\circ}$ and $20^{\circ}$ nozzle inserts was fairly stable and for the most part, no large voltage excursions were seen at the two higher mass flow rates. This was not the case with the $10^{\circ}$ nozzle inserts. With the small constrictor, $10^{\circ}$ half-angle nozzle (insert 3), very large voltage excursions were observed in the tests. From one test period to another, a change of 30 to $40 \mathrm{~V}$ was observed. This was similar to the bi-modal operation observed at low flow rates and described previously. As in those tests, the high voltage mode produced higher performance as shown in figure 5(b). The high voltage mode was observed only in the first test sequence of this nozzle insert. Post-test inspection of this nozzle insert revealed that a significant damage to the constrictor had occurred. This suggests that during low mode operation, the arc attached in the vicinity of the constrictor in the high pressure region. With the large constrictor, $10^{\circ}$ nozzle (insert 6 ), the voltage excursions were not as large but were more than those typically seen with either of the other large diameter nozzles. While this behavior, combined with the differences in electrode geometry noted previously, made interpretation of the data somewhat difficult; some general trends were apparent. In general, anode housing temperatures, as measured by the two color pyrometer, increased with decreasing nozzle angle at constant specific power. While these measurements were not quantitative, the general trend was clear. From the data presented in figure 5 , it is clear that there was no significant difference in performance characteristics between the nozzles with the $15^{\circ}$ and $20^{\circ}$ half-angles in the diverging sections. However, because the $20^{\circ}$ nozzle inserts ran at lower temperatures, data could be collected over a wider operating range with these inserts.

Table I shows that the area ratios of the nozzle inserts in set 1 were in the 240 to 310 range and approximately 100 to 150 greater than their counterparts in set 2 . The approximate posttest values of both constrictor diameter and area ratio are also given in table I. Values for nozzle insert 3 are not given as the damage in the constrictor region was extensive as noted previously. From the table, it can be seen that the area ratios of the set 1 inserts 1 and 2 were significantly reduced from their original values but still about 50 greater than their set 2 counterparts. Originally, after the test series described herein was completed, the inserts in set 2 were to be machined to reduce the area ratio and then rerun in order to separate the effects of both area ratio and constrictor diameter on performance. Because the erosion of the constrictors made a quantitative study of these effects difficult, this was not pursued. The data taken do, however, provide a qualitative understanding of the effects of these parameters. Comparisons of the performance data taken with the $20^{\circ}$ and $15^{\circ}$ half-angle nozzles are shown in figures $6(\mathrm{a})$ and (b), respectively. In both figures, specific impulse is plotted versus specific power for the middle mass flow rate. The data taken at the higher mass flow rate were similar. In one previous study of low power arcjets using hydrogen/nitrogen mixtures to simulate the decomposition products of hydrazine it was found that modest performance gains were obtained as the area ratio was increased to values above $100 .^{25}$ Another study of low power hydrogen/nitrogen arcjets showed that a nozzle insert with a small constrictor diameter and large area ratio slightly outperformed nozzle inserts with larger diameter constrictors and lower area ratios. ${ }^{26}$ Assuming that these trends were to carry over to the hydrogen arcjet, it would be expected that the nozzle inserts of set 1 would outperform those of set 2 . From the data shown in figure 6 , it is clear that there was no significant difference in performance between the nozzle inserts. It is clear that a much more detailed study of the effects of both area ratio and constrictor diameter will be required to completely separate the effects of these variables on performance.

\section{Arcjet Ignition and Transition to Steady State}

A high voltage pulsing technique has been used successfully to start low power arcjets operated on real and simulated hydrazine decomposition products. This has been described in detail elsewhere. ${ }^{29}$ Using the same technique, however, difficulties in ignition and transition to the steady state operating condition were encountered during testing with hydrogen. These starting problems most often occured at lower propellant mass flow rates and on attempted restarts when the thruster body was warm. In order to uncover the nature of this problem, several starting attempts were examined with an oscilloscope during one of the test sessions.

Figure 7 shows an open circuit high voltage pulse used for breakdown of the arcjet electrode gap. A successful start on application of such a pulse is shown in figure 8(a). In this instance, the power supply was set to $16 \mathrm{~A}$ and the mass flow rate was $1.12 \times 10^{-5} \mathrm{~kg} / \mathrm{s}$. The breakdown voltage (BDV) was about $1100 \mathrm{~V}$ and a direct transition to an arc discharge at 13.5 $\mathrm{A}$ and $45 \mathrm{~V}$ was obtained. This BDV was typical value seen in these tests and is low compared to the breakdown voltages normally observed in tests with simulated hydrazine decomposition products. ${ }^{29}$ An unsuccessful start at the same condition is shown in figure 8 (b). Here, the arcjet BDV was about $730 \mathrm{~V}$. This breakdown, however, led to a glow discharge, initially at about $12 \mathrm{~A}$, rather than an arc discharge. The voltage in this mode was greater than the open circuit capability of the PPU and the current bled off the output inductor over a period of about $70 \mu \mathrm{s}$. No transition to an arc mode occurred. An intermediate case, observed under similar starting conditions, is shown in figure 8(c). Here the arcjet initially broke down into a glow discharge but eventually transitioned to an arc. The later two starting attempts were performed after the arcjet had been operated for some time. This suggests that the behavior is not simply statistical but also dependent on local conditions (e. g., temperature and/or pressure) in the electrode region. The physical phenomena 
responsible for the observed starting behavior are not clearly understood at the present time and it is clear that some effort must be directed to this area to ensure successful starting on a routine basis.

\section{Dynamic Arc Characteristics}

Close examination of the dynamic arcjet current-voltage characteristics during some of the testing showed that the thruster operated in two distinct modes. In one mode the arc voltage trace was stable and quiescent with no evidence of high frequency noise. This will be termed high mode operation. In this mode the voltage measured on a fast oscilloscope matched that obtained with an isolated digital multimeter. At times, however, the arc would transition to a noisier mode. In this mode, high frequency oscillations of significant magnitude were observed on the voltage traces. This phenomenon was observed to have characteristics similar to what has been termed a restrike mode. ${ }^{30,31}$ In these studies it was postulated this was the result of the arc being blown downstream and then restriking upstream after the voltage increased to some level. This phenomenon has also been observed in tests of low power arcjets run on simulated hydrazine decomposition products. ${ }^{32}$ As shown in figure 9 , the waveforms observed in this mode resembled a sawtooth with abrupt drops from the high voltage mode followed by gradual recoveries. Frequencies were typically in the 1 to $2 \mathrm{MHz}$ range. It was found to be either continuous or intermittant and the conditions under which the transition occured were found to vary greatly between test periods. Using nozzle insert 1 , a separate test sequence was performed to study these modes in more detail. With this nozzle insert, the modal behavior was found to be fairly repeatable within a given test period and to be impacted by both current level and mass flow rate. Figure 10 illustrates the phenomenon and the effect of current in one test. The high mode of operation is shown in figure 10(a). This oscillogram was obtained at a mass flow rate of $1.61 \times 10^{-5} \mathrm{~kg} / \mathrm{s}$ and a current level of $16 \mathrm{~A}$. Current is shown on the lower trace. The $60 \mu \mathrm{s}, 3 \mathrm{~A}_{\mathrm{p}-\mathrm{p}}$ ripple is due to the power supply output characteristics. A corresponding $7 \mathrm{~V}_{\mathrm{B} \text {-p }}$ ripple on the upper, voltage, trace is approximately 180 out of phase due to the negative current/voltage characteristics of the arc discharge. Figure 10(b) shows the transition that took place as the current was raised to $20 \mathrm{~A}$. Here, high frequency oscillations on the voltage trace can be seen to occur at regular intervals. These coincide with the peaks in the current due to ripple. As the current was further increased to $22 \mathrm{~A}$, the restrike mode became continuous as shown in figure $10(\mathrm{c})$. In this test, the observed trend was found to be repeatable, that is, as the current was lowered the transition back from restrike to high mode took place at approximately the same current level. The same behavior could be brought on by a reduction in the mass flow rate at fixed current. Both reductions in mass flow rate at a constant current and increases in current at a constant mass flow rate have the effect of increasing the specific power level of the arcjet and increasing the anode temperature.

In the tests described above, the peak to peak voltage of the high frequency restrike was about $30 \mathrm{~V}$. Corresponding current fluctuations were less than $1.5 \mathrm{~A}_{\mathrm{p}-\mathrm{p}}$ The center of the voltage band was about $112 \mathrm{~V}$ and this was close to the dc voltage measured with the digital multimeter. Ac rms voltage corrections to the measured dc voltage were judged to be small so it is likely that the use of the measured dc voltage in power calculations did not introduce significant uncertainties. It appeared that the high side of the voltage trace in the restrike mode coincided with the high mode voltage. When the arcjet went into the continuous restrike mode, the dc voltage could drop by nearly $10 \mathrm{~V}$. It should be noted that the restrike mode was typically not this well behaved over time. In one case the restike mode was observed at conditions that had produced high mode operation earlier in the day. Similarly, in an earlier test with a different nozzle insert, a reversal of the restrike mode via increased mass flow rate could not be obtained once it had begun. The causes of the transition between the two modes are not clear at this time. While operation in this mode did not appear to greatly affect the performance of the thruster, further efforts will be required to fully assess impacts on arcjet performance, lifetime, and integration.

\section{Facility Effects}

During tests of nozzle insert 5 , the effects of facility background pressure on thruster performance were examined by performing tests with the diffusion pumps on and off. At the highest mass flow rate, $2.12 \times 10^{-5} \mathrm{~kg} / \mathrm{s}$ the ambient pressure in the test section as measured by a standard ionization gage was on the order of $2 \times 10^{-5} \mathrm{kPa}$ with the diffusion pumps running. Using only the mechanical pumps this pressure increased to the $6 \times 10^{-3} \mathrm{kPa}$ level. In both cases, the standard pressure-area correction was found to be a negligible fraction of the total thrust measurement ( $<0.2$ percent). In the course of testing, the arcjet did display some of the modal behavior. This is shown in the scatter in the voltage/current characteristics documented in figure 11(a). For the most part, the data from the two tests overlap and the performance trends, as shown in the plots of specific impulse versus specific power presented in figure 11(b) indicate that the device was operating normally. From the figures it is clear that the performance was dependent on the background pressure level in the range tested with performance decreasing as the ambient pressure increased. In recent tests at this laboratory, similar trends were obtained using both hydrogen and simulated hydrazine mixtures. ${ }^{28}$ In those tests, it was found that the performance did not continue to decrease as the pressure was raised above the $5 \times 10^{-3} \mathrm{kPa}$ level. This type of dependence has been documented in previous tests of resistojets by numerous authors. ${ }^{33-37}$ In an early test program involving small, evacuated-concentric tube type resistojets, the performance obtained with both hydrogen 
and ammonia was found to degrade significantly as the cell pressure increased from about $1.3 \times 10^{-5}$ to $10 \mathrm{kPa}$. Above $10 \mathrm{kPa}$ the thrust appeared to be relatively independent of facility when both pressure-area and windage corrections were taken into account. ${ }^{33}$ The authors of that particular study suggested that increasing the cell pressure could lead to a thickening of the subsonic boundary layer along the nozzle walls thus decreasing the effective area ratio and performance. In another investigation, ambient pressure increases were found to adversely affect thrust when heated nitrogen was used as the propellant but that the effects were negligible for cold flows. ${ }^{34}$ The authors attributed the observed thrust degradation to losses in propellant enthalpy due to increased convective heat transfer losses from the thruster. Similar conclusions were reached by McKevitt in tests of a hydrazine resistojet ${ }^{35}$ and Kallis in studies of a biowaste resistojet. ${ }^{36}$ In this study, even though the cold flow specific impulse values obtained at the higher mass flow rate and different background pressures were nearly identical, the sensitivity of the thrust measurement precludes definite conclusions. Calorimetric data from the arcjet study noted above indicate that total anode losses do appear to increase with increasing cell pressure and that arcjet performance degrades as the wall temperature is reduced. ${ }^{26}$ While the information available to date suggests that increases in convective losses from the anode are responsible for the observed performance degradation, a more controlled study would be required to verify this with absolute certainty. Regardless of the fundamental cause; it appears that performance measurements taken at elevated background pressures are conservative.

\section{Concluding Remarks}

A preliminary evaluation of hydrogen arcjet operating characteristics was performed using a series of nozzle geometries in a modular arcjet thruster at power levels between 1 and $4 \mathrm{~kW}$. The effects of both nozzle angle and constrictor diameter were investigated in the course of testing. Performance data showed that reducing the nozzle half-angle below the baseline of $20^{\circ}$ did not improve performance and the operating characteristics indicated that serious stability problems occured as the angle was reduced to $10^{\circ}$. The test results also indicated that a more detailed study will be required to fully separate the effects of variables such as constrictor diameter and area ratio on hydrogen arcjet operating characteristics. Specific impulse values in the range of 650 to $1250 \mathrm{sec}$ were observed at efficiencies between 30 and 40 percent.

Over the course of testing, a number of issues surfaced which will require further study if these devices are to be optimized. First, in all cases, damage to the nozzle in the form of melting was observed. While this did not much influence the performance values measured in most cases, the long term effects on thruster life, reliability, and performance were not explored. Ignition and transition to the steady state operating mode was also found to be a problem under some conditions. This was traced to a high voltage discharge mode that occured at breakdown and prevented transition to steady state in many cases. A better understanding of this phenomenon, or at least the conditions under which it occurs, will be required in order to provide a reliable starting sequence. During steady state operation, distinct modal operation was also observed. In some cases, the arcjet would run in a high mode characterized by very little high frequency noise on the voltage trace. At other times, large, high frequency oscillations were seen on the voltage trace. Further study of the phenomenon and it systems impact should be pursued.

Finally, the effects of ambient facility pressure were examined. While the voltage/current characteristics of the device were not much affected by the background pressure, performance degradation similar to that documented in earlier tests of low Reynolds number resistojets was observed. Current understanding suggests that the performance degradation is due to increases in convective losses from the thruster body. The findings also indicate that thrust values obtained under vacuum conditions of $\mathrm{P}_{\mathrm{a}}>1 \times 10^{-2} \mathrm{kPa}$ should be conservative.

\section{Appendix A}

Arcjet efficiency was calculated using the following equation:

$$
\eta=\frac{\left(I_{\text {sph }}\right)^{2}}{\left(\frac{2}{g^{2}}\right)\left(\frac{\left(\mathrm{P}_{\mathrm{a}}\right.}{\mathrm{m}}\right)+\left(\mathrm{I}_{\mathrm{spc}}\right)^{2}}
$$

For this, the following notation was used:

g gravitational acceleration, $9.81 \mathrm{~m} / \mathrm{sec}^{2}$

$\mathrm{h}$ subscript denoting value of quantity with arcjet in operation

c subscript denoting ideal value with no power to the arcjet

$\mathrm{I}_{\mathrm{sp}} \quad$ specific impulse, sec

$\mathrm{m}$ mass flow rate, $\mathrm{kg} / \mathrm{sec}$

$\mathrm{P}_{\mathrm{a}} \quad$ arc power, $\mathrm{w}$

$\eta \quad$ thrust efficiency

$\mathrm{I}_{\mathrm{sph}}$ was calculated from the measured thrusts and mass flow rates.

\section{Acknowledgments}

The authors would like to acknowledge Mr. Charles Smalley for the technical support provided over the course of this project. 


\section{References}

1. Arcjet Application Study. General Electric Co., NASA CR-140076, 1961.

2. John, R.R.: Thirty Kilowatt Plasmajet Rocket-Engine Development. (RAD-TR-64-6, Avco Corp.; NASA Contract NAS5-600), NASA CR-54044, 1964.

3. John, R.R.; Connors, J.F.; and Bennett, S.: Thirty Day Endurance Test of a $30 \mathrm{~kW}$ Arcjet Engine. AIAA Paper 63-274, June 1963.

4. Todd, J.P.: $30 \mathrm{~kW}$ Arcjet Thruster Research. Giannini Scientific Corp., Santa Ana, CA, APL-TDR-64-58, Mar. 1964. (Avail. NTIS, AD601534).

5. Todd, J.P.; and Sheets, R.E.: Development of a Regeneratively Cooled 30-kW Arcjet Engine. AIAA J., vol. 3, no. 1, Jan. 1965, pp. 122-126.

6. Greco, R.V.; and Stoner, W.A.: Development of a Plasmajet Rocket Engine for Attitude Control. GRC-1341-A, Plasmadyne Corp., Santa Ana, CA, Dec. 1961.

7. Ducati, A.C., et al.: "1-kW Arcjet-Engine System-Performance Test, J. Spacecraft Rockets," vol. 1, no. 3, May-June 1964, pp. 327-332.

8. McCaughey, O.J.; Geideman, W.A. , Jr.; and Muller, K.: Research and Advanced Development of a $2 \mathrm{~kW}$ Arc-Jet Thrustor. (GRC1646, Plasmadyne Corp.; NASA Contract NAS3-2521) NASA CR-54035, 1963.

9. Wallner, L.E.; and Czika, J., Jr.: Arcjet Thrustor for Space Propulsion. NASA TD D-2868, 1965.

10. Knowles, S.C.: Arcjet Thruster Research and Technology, Phase II. NASA CR-182276, Rocket Research Co., Redmond, WA, 1991 (to be published).

11. Hardy, T.L.; and Curran, F.M.: "Low Power de Arcjet Operation with Hydrogen/Nitrogen/Ammonia Mixtures," ALAA Paper 87-1948, June 1987 (Also, NASA TM-89876).

12. Knowles, S.C., et al.: Performance Characterization of a Low Power Hydrazine Arcjet. AIAA Paper 87-1057, May 1987.

13. Curran, F.M.; and Haag, T.W.: An Extended Life and Performance Test of a Low Power Arcjet. AIAA Paper 88-3106, July 1988 (Also, NASA TM-100942).

14. Yano, S.E., and Knowles, S.C.: Simulated Flight Qualification Testing of an Engineering Model Arcjet System. presented at the 1989 JANNAF Propulsion Meeting, vol. 1, K.L. Strange and D.S. Eggleston, eds., CPIA-PUBL-515-VOL-1, 1989, pp. 391-402.

15. Knowles, S.C.; Yano, S.E.; and Aadland, R.S.: Qualification and Lifetesting of a Flight Design Hydrazine Arcjet System. AIAA Paper 90-2576, July 1990.

16. Carney, L.M.: Evaluation of the Communications Impact of a Low Power Arcjet Thruster. AIAA Paper 88-3105, July 1988 (Also, NASA TM-100926).

17. Ling, H., et al.: Reflector Performance Degradation Due to an Arcjet Plume. Proceedings of the 1989 Antenna Applications Symposium, P. Mayes, et al., eds., RADC-TR-90-42, Vol. 1, 1990, pp. 163-184.
18. Zafran, S.: Arcjet System Integration Development Program. Final Report, NASA CR-187147, TRW, Inc., Redondo Beach, CA, 1991 (to be published).

19. Zafran, S.: Hydrazine Arcjet Propulsion System Integration Testing. to be presented at the 22nd International Electric Propulsion Conference, Viareggio, Italy, 1991.

20. Deininger, W.D., et al.: 30-kW Ammonia Arcjet Technology. JPL Publication 90-4, NASA CR-186850, Feb. 1990.

21. Haag, T.W.; and Curran, F.M.: High Power Hydrogen Arcjet Performance." AIAA Paper 91-2226, June 1991.

22. Gruber, R.P.: Power Electronics for a $1 \mathrm{~kW}$ Arcjet Thruster. AIAA Paper 86-1507, June 1986. (Also, NASA TM-87340).

23. Gruber, R.P.; Gott, R.W.; and Haag, T.W.: 5-kW Arcjet Power Electronics." AIAA Paper 89-2725, July 1989 (Also, NASA TM-102108).

24. Murch, C.K.; et. al.: Performance Losses in Low-ReynoldsNumber Nozzles. J. Spacecraft Rockets, vol. 5. no. 9, Sept. 1968, pp. 1090-1094.

25. Curran, F.M., et al.: Arcjet Nozzle Area Ratio Effects. 1990 JANNAF Propulsion Meeting, Vol. 2, K.L. Brown and D.S. Eggleston, eds. CPIA-PUBL-550-VOL-2, Oct. 1990, pp. 407-416. (Also, NASA TM-104477).

26. Curran, F.M.; and Sarmiento, C.J.: Low Power Arcjet Performance." AIAA Paper 90-2578, July 1990. (Also, NASA TM-103280).

27. Morren, W.E.; and Curran, F.: Performance and Life Evaluations of a 2 kW-Class Arcjet. AIAA Paper 91-2228, June 1991.

28. Sankovic, J.; and Curran, F.M.: Arcjet Thermal Characteristics. AIAA Paper 91-2456, June 1991.

29. Sarmiento, C.S.; and Gruber, R.P.: Low Power Arcjet Thruster.Pulse Ignition. AIAA Paper 87-1951, July 1987. (Also, NASA TM-100123)

30. Harvey, J.K.; Simpkins, P.G.; and Adcock, B.D.: Instability of Arc Columns. AIAA J., vol. 1, no. 3, Mar. 1963, pp. 714-716.

31. Tateno, H.; and Saito, K.: Anodic Phenomena in Nitrogen Plasma Jet. Japan J. Appl. Physics, Vol. 2, 1963, pp. 192-193.

32. Sarmiento, C.S.: Private Communication.

33. Yoshida, R.Y.; Halbach, C.R.; and Hill, C.S.: Life Test Summary and High-Vacuum Tests of 10-mlb Resistojets. J. Spacecraft Rockets, vol. 8, no. 4, Apr. 1971, pp. 414-416.

34. Manzella, D.H., et al.: Effect of Ambient Pressure on the Performance of a Resistojet. J. Propulsion Power, vol. 5, no. 4, July-Aug. 1989, pp. $452-456$.

35. McKevitt, F.X.: Design and Development Approach for the Augmented Catalytic Thruster (ACT). AIAA Paper 83-1255, June 1983.

36. Kallis, J.M.; Goodman, M.; and Halbach, C.R.: Viscous Effects on Biowaste Resistojet Nozzle Performance. J. Spacecraft Rockets, vol. 9, no. 12, Dec. 1972, pp. 869-875.

37. Sovey, J.S., et al.: Vacuum Chamber Pressure Effects on Thrust Measurements of Low Reynolds Number Nozzles. J. Propulsion Power, vol. 2, no. 5, Sept.-Oct. 1986, pp. 385-389. (Also, NASA TM-86955). 
TABLE 1.-NOZZLE INSERT DIMENSIONS

\begin{tabular}{|c|c|c|c|c|c|c|}
\hline $\begin{array}{c}\text { Nozzle } \\
\text { set } \\
\text { number }\end{array}$ & $\begin{array}{c}\text { Nozzle } \\
\text { insert } \\
\text { number }\end{array}$ & $\begin{array}{c}\text { Constrictor } \\
\text { diameter, } \\
\mathrm{mm}^{\mathrm{a}}\end{array}$ & $\begin{array}{c}\text { Area } \\
\text { ratio }^{\mathrm{a}}\end{array}$ & $\begin{array}{c}\text { Constrictor } \\
\text { diameter, } \\
\mathrm{mm}^{\mathrm{b}}\end{array}$ & $\begin{array}{c}\text { Area } \\
\text { ratio }^{\mathrm{b}}\end{array}$ & $\begin{array}{c}\text { Divergence } \\
\text { angle, } \\
\text { degree }\end{array}$ \\
\hline 1 & 1 & 0.61 & 240 & 0.71 & 170 & 20 \\
1 & 2 & .53 & 310 & 0.66 & 210 & 15 \\
1 & 3 & .53 & 310 & - & - & 10 \\
2 & 4 & .76 & 150 & 0.84 & 120 & 20 \\
2 & 5 & .76 & 150 & 0.75 & 150 & 15 \\
2 & 6 & .76 & 150 & 0.86 & 120 & 10 \\
\hline
\end{tabular}

apre-test

bost-test (Approximate) 
TABLE II.-NOZZLE INSERT 1.

\begin{tabular}{|c|c|c|c|c|c|c|c|c|}
\hline Point - date & $\dot{\mathrm{m}}, \mathrm{kg} / \mathrm{s}$ & Current, A & $\begin{array}{c}\text { Voltage, } \\
\text { (V) }\end{array}$ & $\begin{array}{l}\text { Thrust, } \\
\text { (N) }\end{array}$ & $\begin{array}{c}\text { Power, } \\
\text { (kW) }\end{array}$ & Isp, $s$ & $\mathrm{P} / \dot{\mathrm{m}}, \mathrm{MJ} / \mathrm{kg}$ & Efficiency \\
\hline $1-4 / 15 / 91$ & $1.12 \mathrm{E}-05$ & 9.4 & 120.1 & 0.000 & 1.13 & 864 & 100.8 & 0.341 \\
\hline $2-4 / 15 / 91$ & $1.12 \mathrm{E}-05$ & 10.9 & 114.4 & 0.000 & 1.25 & 888 & 111.3 & 0.328 \\
\hline $3-4 / 27 / 91$ & $1.12 \mathrm{E}-05$ & 11.0 & 96.4 & 0.000 & 1.06 & 806 & 94.7 & 0.316 \\
\hline $4-4 / 27 / 91$ & $1.12 \mathrm{E}-05$ & 15.5 & 100.9 & 0.000 & 1.56 & 953 & 139.6 & 0.303 \\
\hline $5-4 / 27 / 91$ & $1.12 \mathrm{E}-05$ & 15.5 & 86.1 & 0.000 & 1.33 & 855 & 119.2 & 0.285 \\
\hline $6-4 / 27 / 91$ & $1.12 \mathrm{E}-05$ & 21.7 & 88.0 & 0.000 & 1.91 & 1014 & 170.5 & 0.282 \\
\hline $7-4 / 15 / 91$ & $1.61 \mathrm{E}-05$ & 6.9 & 146.1 & 0.000 & 1.01 & 719 & 62.6 & 0.372 \\
\hline $8-4 / 15 / 91$ & $1.61 \mathrm{E}-05$ & 9.2 & 134.7 & 0.000 & 1.24 & 795 & 77.0 & 0.374 \\
\hline $9-4 / 15 / 91$ & $1.61 \mathrm{E}-05$ & 9.2 & 135.7 & 0.000 & 1.25 & 812 & 77.5 & 0.388 \\
\hline $10-4 / 15 / 91$ & $1.61 \mathrm{E}-05$ & 9.2 & 135.4 & 0.000 & 1.25 & 821 & 77.4 & 0.397 \\
\hline $11-4 / 15 / 91$ & $1.61 \mathrm{E}-05$ & 9.2 & 135.4 & 0.000 & 1.25 & 804 & 77.4 & 0.380 \\
\hline $12-4 / 15 / 91$ & $1.61 \mathrm{E}-05$ & 9.2 & 134.8 & 0.000 & 1.24 & 796 & 77.0 & 0.375 \\
\hline $13-4 / 15 / 91$ & $1.61 \mathrm{E}-05$ & 10.5 & 131.4 & 0.000 & 1.38 & 846 & 85.7 & 0.382 \\
\hline $14-4 / 27 / 91$ & 1.61E-05 & 11.5 & 132.6 & 0.000 & 1.52 & 858 & 94.7 & 0.358 \\
\hline $15-4 / 27 / 91$ & $1.61 \mathrm{E}-05$ & 11.5 & 133.5 & 0.000 & 1.54 & 875 & 95.4 & 0.369 \\
\hline $16-4 / 15 / 91$ & $1.61 \mathrm{E}-05$ & 11.6 & 129.7 & 0.000 & 1.50 & 872 & 93.4 & 0.374 \\
\hline $17-4 / 16 / 91$ & $1.61 \mathrm{E}-05$ & 11.6 & 128.8 & 0.000 & 1.49 & 856 & 92.8 & 0.363 \\
\hline $18-4 / 13 / 91$ & $1.61 \mathrm{E}-05$ & 15.6 & 124.3 & 0.000 & 1.94 & 961 & 120.4 & 0.356 \\
\hline $19-4 / 16 / 91$ & $1.61 \mathrm{E}-05$ & 16.0 & 124.8 & 0.000 & 2.00 & 973 & 124.0 & 0.355 \\
\hline $20-4 / 16 / 91$ & $1.61 \mathrm{E}-05$ & 16.0 & 126.1 & 0.000 & 2.02 & 991 & 125.3 & 0.364 \\
\hline $21-4 / 27 / 91$ & $1.61 \mathrm{E}-05$ & 16.1 & 126.2 & 0.000 & 2.03 & 977 & 126.2 & 0.352 \\
\hline $22-4 / 27 / 91$ & $1.61 \mathrm{E}-05$ & 16.1 & 128.8 & 0.000 & 2.07 & 994 & 128.8 & 0.357 \\
\hline $23-4 / 13 / 91$ & $1.61 \mathrm{E}-05$ & 18.5 & 123.0 & 0.000 & 2.28 & 1027 & 141.3 & 0.348 \\
\hline $24-4 / 27 / 91$ & $1.61 \mathrm{E}-05$ & 21.1 & 122.4 & 0.000 & 2.58 & 1079 & 160.4 & 0.340 \\
\hline $25-4 / 16 / 91$ & $1.61 \mathrm{E}-05$ & 21.2 & 123.1 & 0.000 & 2.61 & 1085 & 162.1 & 0.340 \\
\hline $26-4 / 13 / 91$ & $1.61 \mathrm{E}-05$ & 21.8 & 122.8 & 0.000 & 2.68 & 1093 & 166.3 & 0.337 \\
\hline $27-4 / 16 / 91$ & $1.61 \mathrm{E}-05$ & 24.7 & 121.1 & 0.000 & 2.99 & 1152 & 185.8 & 0.336 \\
\hline $28-4 / 27 / 91$ & $1.61 \mathrm{E}-05$ & 25.0 & 119.6 & 0.000 & 2.99 & 1130 & 185.7 & 0.323 \\
\hline $29-4 / 13 / 91$ & $1.61 \mathrm{E}-05$ & 25.1 & 121.5 & 0.000 & 3.05 & 1143 & 189.4 & 0.324 \\
\hline $30-4 / 16 / 91$ & $1.61 \mathrm{E}-05$ & 29.0 & 120.8 & 0.000 & 3.50 & 1237 & 217.6 & 0.331 \\
\hline $31-4 / 15 / 91$ & $2.12 \mathrm{E}-05$ & 6.8 & 161.0 & 0.000 & 1.09 & 662 & 51.6 & 0.377 \\
\hline $32-4 / 15 / 91$ & $2.12 \mathrm{E}-05$ & 8.0 & 153.5 & 0.000 & 1.23 & 700 & 57.9 & 0.379 \\
\hline $33-4 / 15 / 91$ & $2.12 \mathrm{E}-05$ & 8.0 & 153.1 & 0.000 & 1.22 & 713 & 57.8 & 0.394 \\
\hline $34-4 / 15 / 91$ & $2.12 \mathrm{E}-05$ & 9.5 & 147.8 & 0.000 & 1.40 & 758 & 66.2 & 0.392 \\
\hline $35-4 / 15 / 91$ & $2.12 \mathrm{E}-05$ & 9.5 & 147.2 & 0.000 & 1.40 & 745 & 66.0 & 0.380 \\
\hline $36-4 / 27 / 91$ & $2.12 \mathrm{E}-05$ & 10.0 & 145.3 & 0.000 & 1.45 & 768 & 68.5 & 0.389 \\
\hline $37-4 / 15 / 91$ & $2.12 \mathrm{E}-05$ & 11.1 & 142.8 & 0.000 & 1.59 & 790 & 74.8 & 0.380 \\
\hline $38-4 / 15 / 91$ & $2.12 \mathrm{E}-05$ & 11.1 & 143.0 & 0.000 & 1.59 & 803 & 74.9 & 0.392 \\
\hline $39-4 / 27 / 91$ & $2.12 \mathrm{E}-05$ & 14.5 & 137.2 & 0.000 & 1.99 & 878 & 93.8 & 0.377 \\
\hline $40-4 / 27 / 91$ & $2.12 \mathrm{E}-05$ & 14.5 & 141.6 & 0.000 & 2.05 & 897 & 96.8 & 0.382 \\
\hline $41-4 / 27 / 91$ & $2.12 \mathrm{E}-05$ & 19.4 & 134.5 & 0.000 & 2.61 & 994 & 123.1 & 0.373 \\
\hline $42-4 / 27 / 91$ & $2.12 \mathrm{E}-05$ & 19.4 & 138.6 & 0.000 & 2.69 & 1013 & 126.8 & 0.376 \\
\hline $43-4 / 27 / 91$ & $2.12 \mathrm{E}-05$ & 23.3 & 134.7 & 0.000 & 3.14 & 1071 & 148.0 & 0.362 \\
\hline $44-4 / 27 / 91$ & $2.12 \mathrm{E}-05$ & 23.3 & 137.5 & 0.000 & 3.20 & 1078 & 151.1 & 0.359 \\
\hline $45-4 / 27 / 91$ & $2.12 \mathrm{E}-05$ & 27.1 & 134.0 & 0.000 & 3.63 & 1142 & 171.3 & 0.357 \\
\hline $46-4 / 27 / 91$ & $2.12 \mathrm{E}-05$ & 31.7 & 130.7 & 0.000 & 4.14 & 1213 & 195.4 & 0.354 \\
\hline
\end{tabular}


TABLE III.-NOZZLE INSERT 2.

\begin{tabular}{|r|c|c|c|c|c|c|c|c|}
\hline Point - date & $\dot{\mathrm{m}}, \mathrm{kg} / \mathrm{s}$ & Current, A & $\begin{array}{c}\text { Voltage, } \\
(\mathrm{V})\end{array}$ & $\begin{array}{c}\text { Thrust, } \\
(\mathrm{N})\end{array}$ & $\begin{array}{c}\text { Power, } \\
(\mathrm{kW})\end{array}$ & Isp, s & P/m, MJ/kg & Efficiency \\
\hline $1-4 / 22 / 91$ & $1.12 \mathrm{E}-05$ & 7.9 & 136.2 & 0.094 & 1.08 & 854 & 96.1 & 0.350 \\
$2-4 / 23 / 91$ & $1.12 \mathrm{E}-05$ & 12.4 & 125.5 & 0.109 & 1.56 & 991 & 138.9 & 0.330 \\
$3-4 / 23 / 91$ & $1.12 \mathrm{E}-05$ & 15.6 & 118.3 & 0.113 & 1.85 & 1027 & 164.8 & 0.301 \\
$4-4 / 23 / 91$ & $1.12 \mathrm{E}-05$ & 18.1 & 116.1 & 0.118 & 2.10 & 1076 & 187.6 & 0.291 \\
& & & & & & & & \\
$5-4 / 22 / 91$ & $1.61 \mathrm{E}-05$ & 6.4 & 164.4 & 0.122 & 1.05 & 772 & 65.4 & 0.412 \\
$6-4 / 22 / 91$ & $1.61 \mathrm{E}-05$ & 8.3 & 155.2 & 0.133 & 1.29 & 840 & 80.0 & 0.403 \\
$7-4 / 23 / 91$ & $1.61 \mathrm{E}-05$ & 10.0 & 153.7 & 0.145 & 1.54 & 919 & 95.5 & 0.408 \\
$8-4 / 22 / 91$ & $1.61 \mathrm{E}-05$ & 10.5 & 150.3 & 0.145 & 1.58 & 916 & 98.0 & 0.395 \\
$9-4 / 23 / 91$ & $1.61 \mathrm{E}-05$ & 11.3 & 149.6 & 0.149 & 1.69 & 944 & 105.0 & 0.393 \\
$10-4 / 23 / 91$ & $1.61 \mathrm{E}-05$ & 11.3 & 149.9 & 0.146 & 1.69 & 927 & 105.2 & 0.378 \\
$11-4 / 23 / 91$ & $1.61 \mathrm{E}-05$ & 14.0 & 145.6 & 0.159 & 2.04 & 1004 & 126.6 & 0.371 \\
$12-4 / 23 / 91$ & $1.61 \mathrm{E}-05$ & 16.7 & 142.3 & 0.165 & 2.38 & 1047 & 147.6 & 0.347 \\
$13-4 / 23 / 91$ & $1.61 \mathrm{E}-05$ & 19.3 & 139.6 & 0.172 & 2.69 & 1089 & 167.3 & 0.333 \\
& & & & & & & & \\
$14-4 / 22 / 91$ & $2.12 \mathrm{E}-05$ & 6.0 & 184.5 & 0.145 & 1.11 & 696 & 52.2 & 0.413 \\
$15-4 / 22 / 91$ & $2.12 \mathrm{E}-05$ & 8.5 & 168.6 & 0.162 & 1.43 & 780 & 67.6 & 0.407 \\
$16-4 / 22 / 91$ & $2.12 \mathrm{E}-05$ & 9.6 & 165.7 & 0.172 & 1.59 & 825 & 75.0 & 0.413 \\
\hline
\end{tabular}

TABLE IV.-NOZZLE INSERT 3.

\begin{tabular}{|r|c|c|c|c|c|c|c|c|}
\hline Point - date & $\dot{m}, \mathrm{~kg} / \mathrm{s}$ & Current, A & $\begin{array}{c}\text { Voltage, } \\
(\mathrm{V})\end{array}$ & $\begin{array}{c}\text { Thrust, } \\
(\mathrm{N})\end{array}$ & $\begin{array}{c}\text { Power, } \\
(\mathrm{kW})\end{array}$ & Isp, s & P/m, MJ/kg & Efficiency \\
\hline $1-4 / 24 / 91$ & $1.61 \mathrm{E}-05$ & 13.9 & 146.5 & 0.144 & 2.04 & 909 & 126.5 & 0.304 \\
$2-4 / 24 / 91$ & $1.61 \mathrm{E}-05$ & 17.1 & 133.3 & 0.148 & 2.28 & 935 & 141.6 & 0.288 \\
$3-4 / 24 / 91$ & $1.61 \mathrm{E}-05$ & 17.1 & 133.5 & 0.145 & 2.28 & 918 & 141.8 & 0.277 \\
$4-4 / 24 / 91$ & $1.61 \mathrm{E}-05$ & 17.1 & 133.5 & 0.146 & 2.28 & 926 & 141.8 & 0.282 \\
$5-5 / 13 / 91$ & $1.61 \mathrm{E}-05$ & 10.0 & 98.6 & 0.105 & 0.99 & 666 & 61.2 & 0.326 \\
$6-5 / 13 / 91$ & $1.61 \mathrm{E}-05$ & 10.0 & 99.8 & 0.104 & 1.00 & 659 & 62.0 & 0.315 \\
$7-5 / 13 / 91$ & $1.61 \mathrm{E}-05$ & 10.0 & 96.2 & 0.103 & 0.96 & 650 & 59.8 & 0.318 \\
$8-5 / 14 / 91$ & $1.61 \mathrm{E}-05$ & 10.0 & 99.9 & 0.105 & 1.00 & 665 & 62.0 & 0.321 \\
$9-5 / 13 / 91$ & $1.61 \mathrm{E}-05$ & 17.1 & 84.6 & 0.115 & 1.45 & 727 & 89.9 & 0.271 \\
$10-5 / 14 / 91$ & $1.61 \mathrm{E}-05$ & 17.1 & 94.7 & 0.120 & 1.62 & 758 & 100.6 & 0.264 \\
$11-5 / 13 / 91$ & $1.61 \mathrm{E}-05$ & 22.1 & 81.1 & 0.123 & 1.79 & 779 & 111.3 & 0.252 \\
$12-5 / 14 / 91$ & $1.61 \mathrm{E}-05$ & 22.0 & 90.2 & 0.128 & 1.98 & 809 & 123.3 & 0.247 \\
$13-5 / 14 / 91$ & $1.61 \mathrm{E}-05$ & 24.1 & 86.5 & 0.124 & 2.08 & 784 & 129.5 & 0.221 \\
& & & & & & & & \\
$14-5 / 13 / 91$ & $2.12 \mathrm{E}-05$ & 15.3 & 101.9 & 0.155 & 1.56 & 746 & 73.5 & 0.345 \\
$15-5 / 13 / 91$ & $2.12 \mathrm{E}-05$ & 15.4 & 99.3 & 0.154 & 1.53 & 741 & 72.1 & 0.346 \\
$16-5 / 14 / 91$ & $2.12 \mathrm{E}-05$ & 15.3 & 108.1 & 0.159 & 1.65 & 764 & 78.0 & 0.341 \\
$17-5 / 14 / 91$ & $2.12 \mathrm{E}-05$ & 15.4 & 107.8 & 0.160 & 1.66 & 770 & 78.3 & 0.346 \\
$18-5 / 14 / 91$ & $2.12 \mathrm{E}-05$ & 15.3 & 107.5 & 0.159 & 1.64 & 764 & 77.6 & 0.343 \\
$19-5 / 14 / 91$ & $2.12 \mathrm{E}-05$ & 15.3 & 105.6 & 0.159 & 1.62 & 764 & 76.2 & 0.349 \\
$20-5 / 13 / 91$ & $2.12 \mathrm{E}-05$ & 21.5 & 96.0 & 0.169 & 2.06 & 811 & 97.4 & 0.312 \\
$21-5 / 14 / 91$ & $2.12 \mathrm{E}-05$ & 21.5 & 101.8 & 0.175 & 2.19 & 841 & 103.2 & 0.317 \\
$22-5 / 14 / 91$ & $2.12 \mathrm{E}-05$ & 21.5 & 100.8 & 0.171 & 2.17 & 822 & 102.2 & 0.305 \\
$23-5 / 13 / 91$ & $2.12 \mathrm{E}-05$ & 26.8 & 97.0 & 0.181 & 2.60 & 871 & 122.6 & 0.288 \\
$24-5 / 14 / 91$ & $2.12 \mathrm{E}-05$ & 26.8 & 98.5 & 0.179 & 2.64 & 861 & 124.5 & 0.277 \\
\hline
\end{tabular}


TABLE V.-NOZZLE INSERT 4.

\begin{tabular}{|c|c|c|c|c|c|c|c|c|}
\hline Point - date & $\dot{\mathrm{m}}, \mathrm{kg} / \mathrm{s}$ & Current, A & $\begin{array}{c}\text { Voltage, } \\
(\mathrm{V})\end{array}$ & $\begin{array}{c}\text { Thrust, } \\
(\mathrm{N})\end{array}$ & $\begin{array}{c}\text { Power, } \\
(\mathrm{kW})\end{array}$ & Isp, s & P/m, MJ/kg & Efficiency \\
\hline $1-5 / 4 / 91$ & $1.61 \mathrm{E}-05$ & 10.0 & 102.9 & 0.118 & 1.03 & 746 & 63.9 & 0.393 \\
$2-5 / 4 / 91$ & $1.61 \mathrm{E}-05$ & 16.1 & 93.1 & 0.137 & 1.50 & 866 & 93.1 & 0.371 \\
$3-5 / 4 / 91$ & $1.61 \mathrm{E}-05$ & 16.1 & 93.3 & 0.137 & 1.50 & 866 & 93.3 & 0.370 \\
$4-5 / 4 / 91$ & $1.61 \mathrm{E}-05$ & 16.1 & 92.9 & 0.134 & 1.50 & 849 & 92.9 & 0.357 \\
$5-5 / 4 / 91$ & $1.61 \mathrm{E}-05$ & 22.3 & 91.9 & 0.157 & 2.05 & 995 & 127.3 & 0.362 \\
$6-5 / 4 / 91$ & $1.61 \mathrm{E}-05$ & 28.5 & 91.0 & 0.173 & 2.59 & 1098 & 161.1 & 0.351 \\
$7-5 / 4 / 91$ & $1.61 \mathrm{E}-05$ & 34.4 & 90.6 & 0.190 & 3.12 & 1201 & 193.6 & 0.351 \\
& & & & & & & & \\
$8-5 / 4 / 91$ & $2.12 \mathrm{E}-05$ & 15.1 & 100.0 & 0.163 & 1.51 & 782 & 71.2 & 0.390 \\
$9-5 / 4 / 91$ & $2.12 \mathrm{E}-05$ & 17.7 & 97.8 & 0.172 & 1.73 & 827 & 81.7 & 0.384 \\
$10-5 / 4 / 91$ & $2.12 \mathrm{E}-05$ & 17.7 & 100.7 & 0.173 & 1.78 & 834 & 84.1 & 0.379 \\
$11-5 / 4 / 91$ & $2.12 \mathrm{E}-05$ & 17.7 & 102.1 & 0.175 & 1.81 & 840 & 85.2 & 0.380 \\
$12-5 / 4 / 91$ & $2.12 \mathrm{E}-05$ & 21.0 & 98.5 & 0.186 & 2.07 & 893 & 97.6 & 0.377 \\
$13-5 / 4 / 91$ & $2.12 \mathrm{E}-05$ & 26.0 & 98.3 & 0.203 & 2.56 & 977 & 120.6 & 0.368 \\
$14-5 / 4 / 91$ & $2.12 \mathrm{E}-05$ & 31.4 & 97.8 & 0.222 & 3.07 & 1068 & 144.9 & 0.369 \\
$15-5 / 4 / 91$ & $2.12 \mathrm{E}-05$ & 36.4 & 98.1 & 0.244 & 3.57 & 1173 & 168.4 & 0.383 \\
\hline
\end{tabular}

TABLE VI.-NOZZLE INSERT 5.

\begin{tabular}{|c|c|c|c|c|c|c|c|c|}
\hline Point - date & $\dot{\mathrm{m}}, \mathrm{kg} / \mathrm{s}$ & Current, $\mathrm{A}$ & $\begin{array}{c}\text { Voltage, } \\
(\mathrm{V})\end{array}$ & $\begin{array}{c}\text { Thrust, } \\
(\mathrm{N})\end{array}$ & $\begin{array}{c}\text { Power, } \\
(\mathrm{kW})\end{array}$ & Isp, s & $\mathrm{P} / \dot{\mathrm{m}}, \mathrm{MJ} / \mathrm{kg}$ & Efficiency \\
\hline $1-4 / 4 / 91$ & $1.12 \mathrm{E}-05$ & 16.1 & 93.0 & 0.101 & 1.50 & 915 & 133.7 & 0.292 \\
& & & & & & & & \\
$2-4 / 4 / 91$ & $1.61 \mathrm{E}-05$ & 9.5 & 114.3 & 0.122 & 1.09 & 772 & 67.4 & 0.400 \\
$3-4 / 4 / 91$ & $1.61 \mathrm{E}-05$ & 13.5 & 108.2 & 0.138 & 1.46 & 874 & 90.7 & 0.387 \\
$4-4 / 4 / 91$ & $1.61 \mathrm{E}-05$ & 19.5 & 105.9 & 0.155 & 2.07 & 984 & 128.3 & 0.352 \\
& & & & & & & & \\
$5-4 / 4 / 91$ & $2.12 \mathrm{E}-05$ & 9.8 & 124.5 & 0.151 & 1.22 & 728 & 57.6 & 0.413 \\
$6-4 / 4 / 91$ & $2.12 \mathrm{E}-05$ & 12.5 & 120.6 & 0.165 & 1.51 & 793 & 71.1 & 0.401 \\
$7-4 / 4 / 91$ & $2.12 \mathrm{E}-05$ & 12.5 & 123.9 & 0.170 & 1.55 & 818 & 73.1 & 0.417 \\
$8-4 / 4 / 91$ & $2.12 \mathrm{E}-05$ & 15.1 & 119.7 & 0.180 & 1.81 & 863 & 85.3 & 0.401 \\
$9-4 / 4 / 91$ & $2.12 \mathrm{E}-05$ & 17.1 & 115.6 & 0.188 & 1.98 & 902 & 93.2 & 0.402 \\
$10-4 / 4 / 91$ & $2.12 \mathrm{E}-05$ & 17.1 & 120.3 & 0.190 & 2.06 & 915 & 97.0 & 0.398 \\
$11-4 / 4 / 91$ & $2.12 \mathrm{E}-05$ & 17.1 & 119.1 & 0.189 & 2.04 & 909 & 96.1 & 0.396 \\
$12-4 / 4 / 91$ & $2.12 \mathrm{E}-05$ & 20.0 & 112.4 & 0.194 & 2.25 & 934 & 106.0 & 0.381 \\
$13-4 / 4 / 91$ & $2.12 \mathrm{E}-05$ & 23.0 & 113.0 & 0.205 & 2.60 & 986 & 122.6 & 0.369 \\
\hline
\end{tabular}


TABLE VII.-NOZZLE INSERT 6.

\begin{tabular}{|c|c|c|c|c|c|c|c|c|}
\hline Point - date & $\dot{\mathrm{m}}, \mathrm{kg} / \mathrm{s}$ & Current, A & $\begin{array}{l}\text { Voltage, } \\
\text { (V) }\end{array}$ & $\begin{array}{l}\text { Thrust, } \\
\text { (N) }\end{array}$ & $\begin{array}{l}\text { Power, } \\
(\mathrm{kW})\end{array}$ & Isp, $s$ & $\mathrm{P} / \dot{\mathrm{m}}, \mathrm{MJ} / \mathrm{kg}$ & Efficiency \\
\hline $1-4 / 09 / 91$ & $1.12 \mathrm{E}-05$ & 9.9 & 100.8 & 0.088 & 1.00 & 803 & 89.1 & 0.332 \\
\hline $2-4 / 11 / 91$ & $1.12 \mathrm{E}-05$ & 12.5 & 96.3 & 0.080 & 1.20 & 727 & 107.5 & 0.227 \\
\hline $3-4 / 09 / 91$ & $1.12 \mathrm{E}-05$ & 13.9 & 95.2 & 0.094 & 1.32 & 852 & 118.2 & 0.285 \\
\hline $4-4 / 11 / 91$ & $1.12 \mathrm{E}-05$ & 14.5 & 91.6 & 0.080 & 1.33 & 727 & 118.6 & 0.207 \\
\hline $5-4 / 09 / 91$ & $1.61 \mathrm{E}-05$ & 9.7 & 109.1 & 0.119 & 1.06 & 753 & 65.7 & 0.390 \\
\hline $6-4 / 11 / 91$ & $1.61 \mathrm{E}-05$ & 9.9 & 111.1 & 0.111 & 1.10 & 703 & 68.3 & 0.327 \\
\hline $7-4 / 09 / 91$ & $1.61 \mathrm{E}-05$ & 11.8 & 108.6 & 0.128 & 1.28 & 812 & 79.6 & 0.379 \\
\hline $8-4 / 09 / 91$ & $1.61 \mathrm{E}-05$ & 11.8 & 109.9 & 0.131 & 1.30 & 829 & 80.5 & 0.390 \\
\hline $9-4 / 09 / 91$ & $1.61 \mathrm{E}-05$ & 14.1 & 106.1 & 0.132 & 1.50 & 838 & 92.9 & 0.348 \\
\hline $10-5 / 16 / 91$ & $1.61 \mathrm{E}-05$ & 17.2 & 107.9 & 0.141 & 1.86 & 895 & 115.3 & 0.322 \\
\hline $11-5 / 16 / 91$ & $1.61 \mathrm{E}-05$ & 17.2 & 107.2 & 0.141 & 1.84 & 895 & 114.5 & 0.324 \\
\hline $12-5 / 16 / 91$ & $1.61 \mathrm{E}-05$ & 25.0 & 103.1 & 0.151 & 2.58 & 955 & 160.1 & 0.267 \\
\hline $13-4 / 9 / 91$ & 2.12E-05 & 9.9 & 122.2 & 0.154 & 1.21 & 739 & 57.1 & 0.429 \\
\hline $14-4 / 9 / 91$ & $2.12 \mathrm{E}-05$ & 12.7 & 118.6 & 0.166 & 1.51 & 797 & 71.0 & 0.406 \\
\hline $15-4 / 9 / 91$ & 2.12E-05 & 15.5 & 120.7 & 0.178 & 1.87 & 855 & 88.2 & 0.381 \\
\hline $16-4 / 9 / 91$ & $2.12 \mathrm{E}-05$ & 15.5 & 108.5 & 0.174 & 1.68 & 835 & 79.3 & 0.402 \\
\hline $17-4 / 9 / 91$ & $2.12 \mathrm{E}-05$ & 18.0 & 107.6 & 0.180 & 1.94 & 868 & 91.4 & 0.379 \\
\hline $18-4 / 9 / 91$ & $2.12 \mathrm{E}-05$ & 22.3 & 104.9 & 0.194 & 2.34 & 932 & 110.3 & 0.365 \\
\hline $19-5 / 16 / 91$ & $2.12 \mathrm{E}-05$ & 15.5 & 133.7 & 0.185 & 2.07 & 889 & 97.8 & 0.373 \\
\hline $20-5 / 16 / 91$ & $2.12 \mathrm{E}-05$ & 16.6 & 134.5 & 0.183 & 2.23 & 882 & 105.3 & 0.342 \\
\hline $21-5 / 16 / 91$ & $2.12 \mathrm{E}-05$ & 17.2 & 131.8 & 0.189 & 2.27 & 908 & 106.9 & 0.357 \\
\hline $22-5 / 16 / 91$ & $2.12 \mathrm{E}-05$ & 17.2 & 127.4 & 0.186 & 2.19 & 895 & 103.4 & 0.358 \\
\hline $23-5 / 16 / 91$ & $2.12 \mathrm{E}-05$ & 17.2 & 120.0 & 0.178 & 2.06 & 856 & 97.4 & 0.347 \\
\hline $24-5 / 16 / 91$ & $2.12 \mathrm{E}-05$ & 17.2 & 113.1 & 0.179 & 1.95 & 862 & 91.8 & 0.373 \\
\hline $25-5 / 16 / 91$ & $2.12 \mathrm{E}-05$ & 20.0 & 126.0 & 0.192 & 2.52 & 921 & 118.9 & 0.332 \\
\hline $26-5 / 16 / 91$ & $2.12 \mathrm{E}-05$ & 23.0 & 126.4 & 0.202 & 2.91 & 973 & 137.1 & 0.323 \\
\hline
\end{tabular}




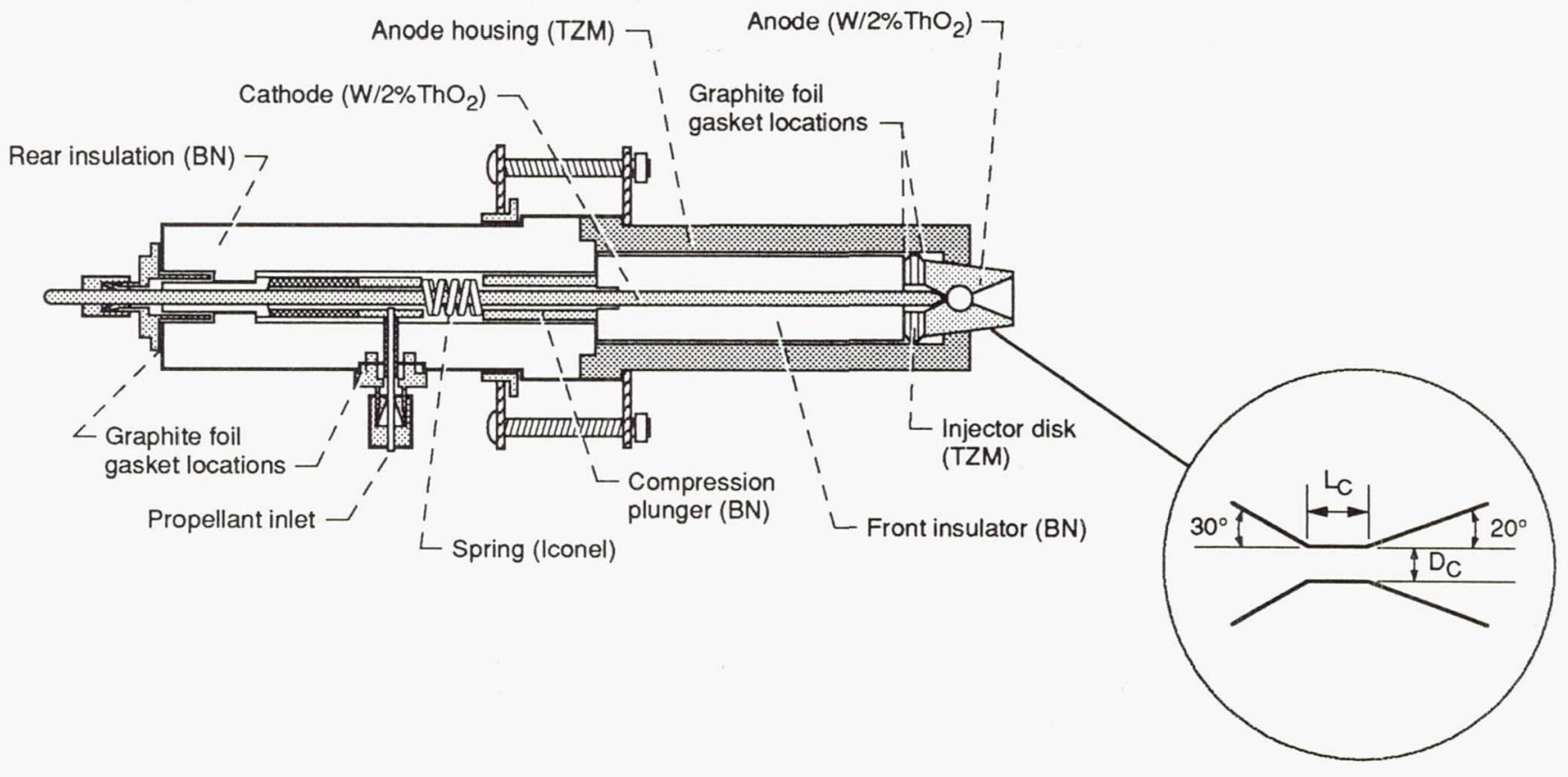

Figure 1.-Cross-sectional schematic of the modular arcjet.

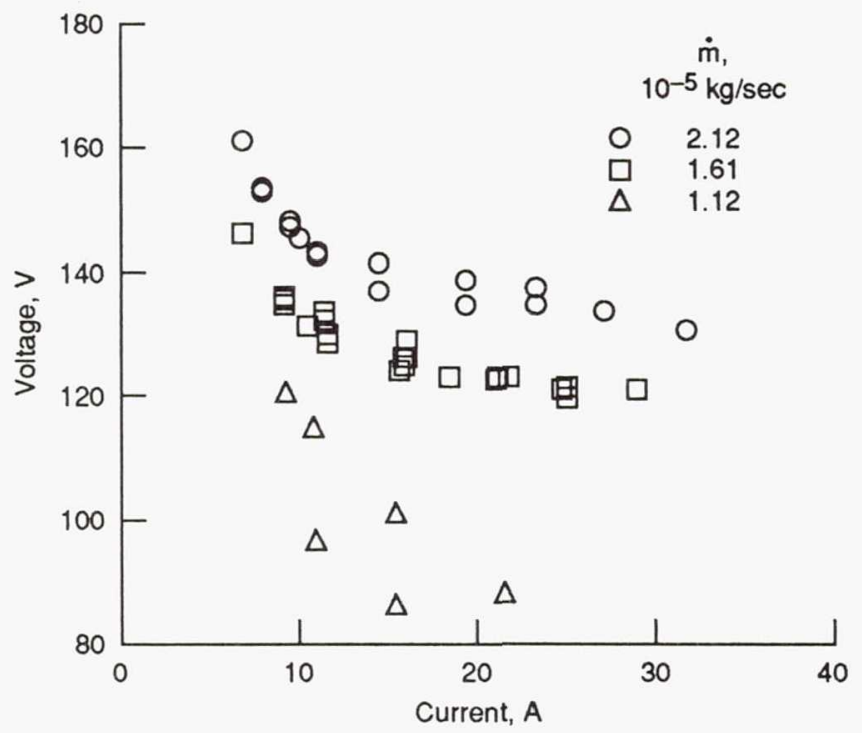

Figure 2.-Current/voltage characteristics - nozzle insert 1. 


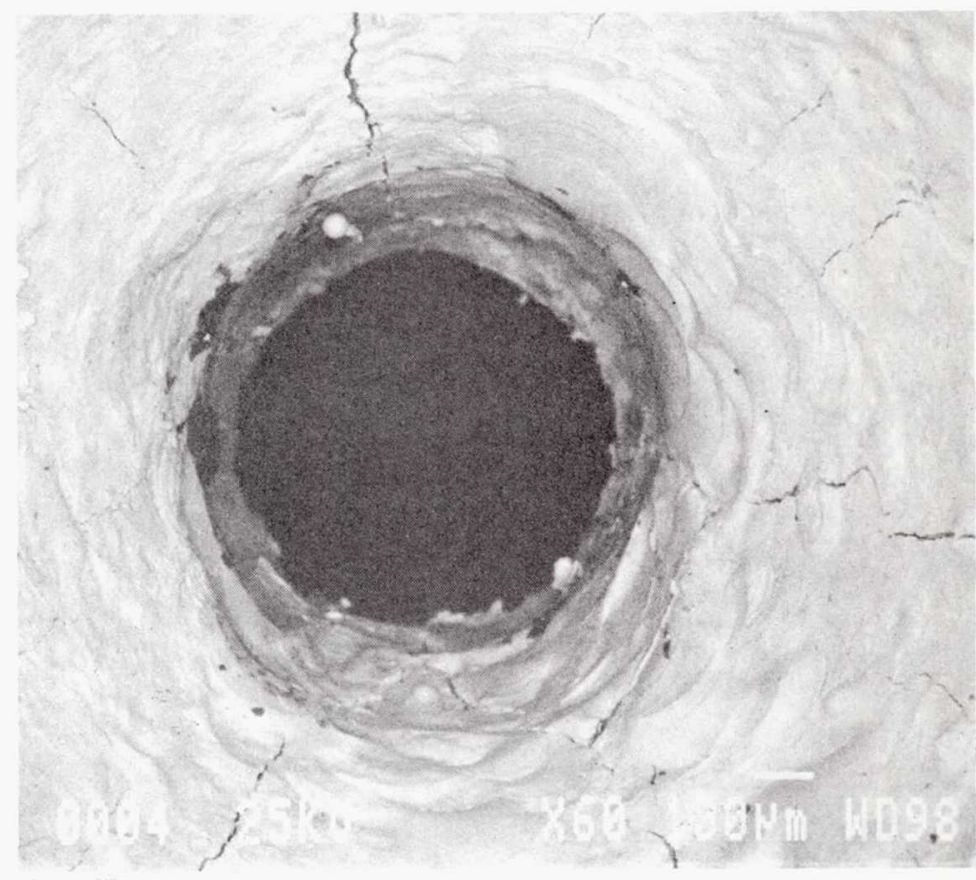

(a) Converging side $\times 60$.

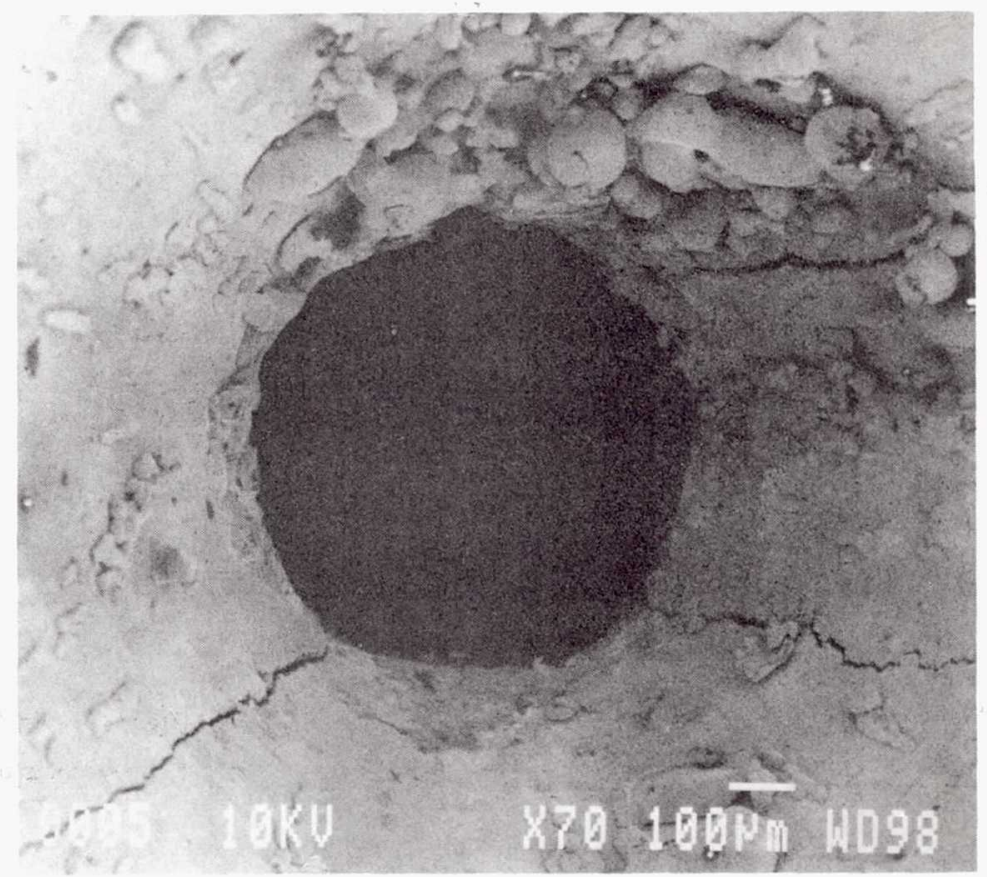

(b) Diverging side $\times 70$.

Figure 3.-Post test condition - nozzle insert 1. 


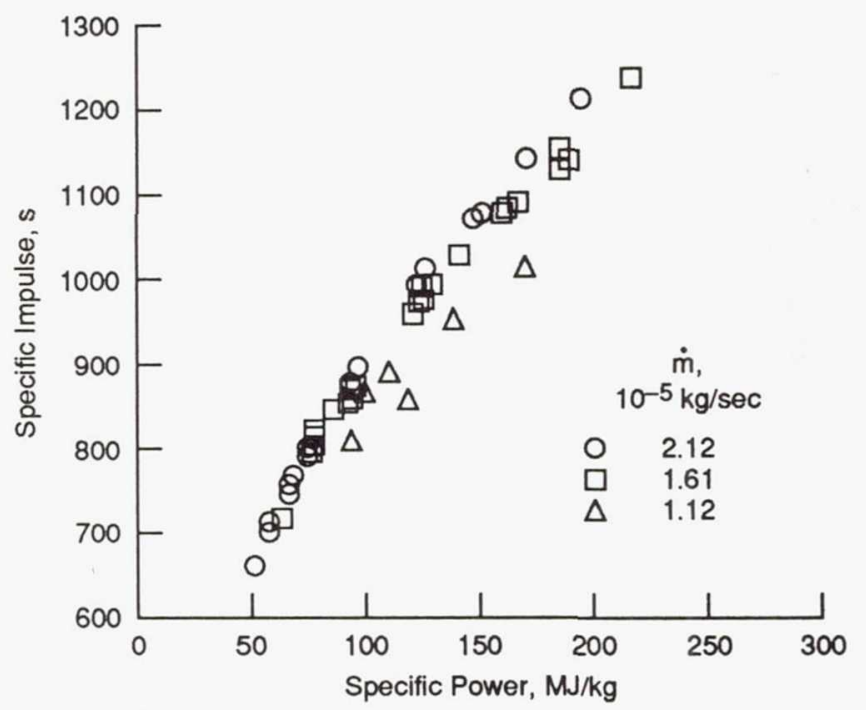

(a) Specific impulse versus specific power.

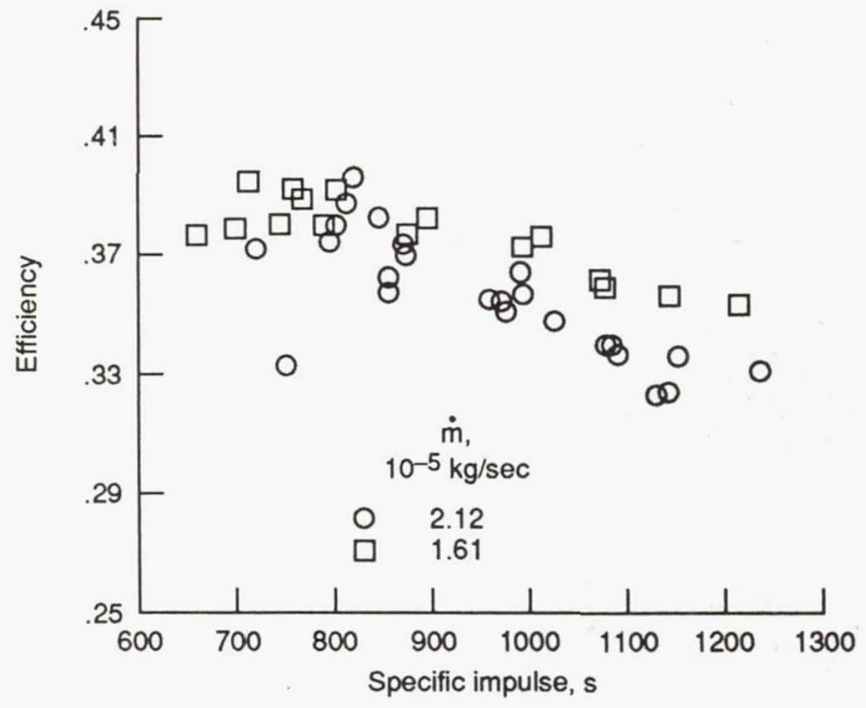

(b) Efficiency versus specific impulse.

Figure 4.-Arcjet performance characteristics - nozzle insert 1.

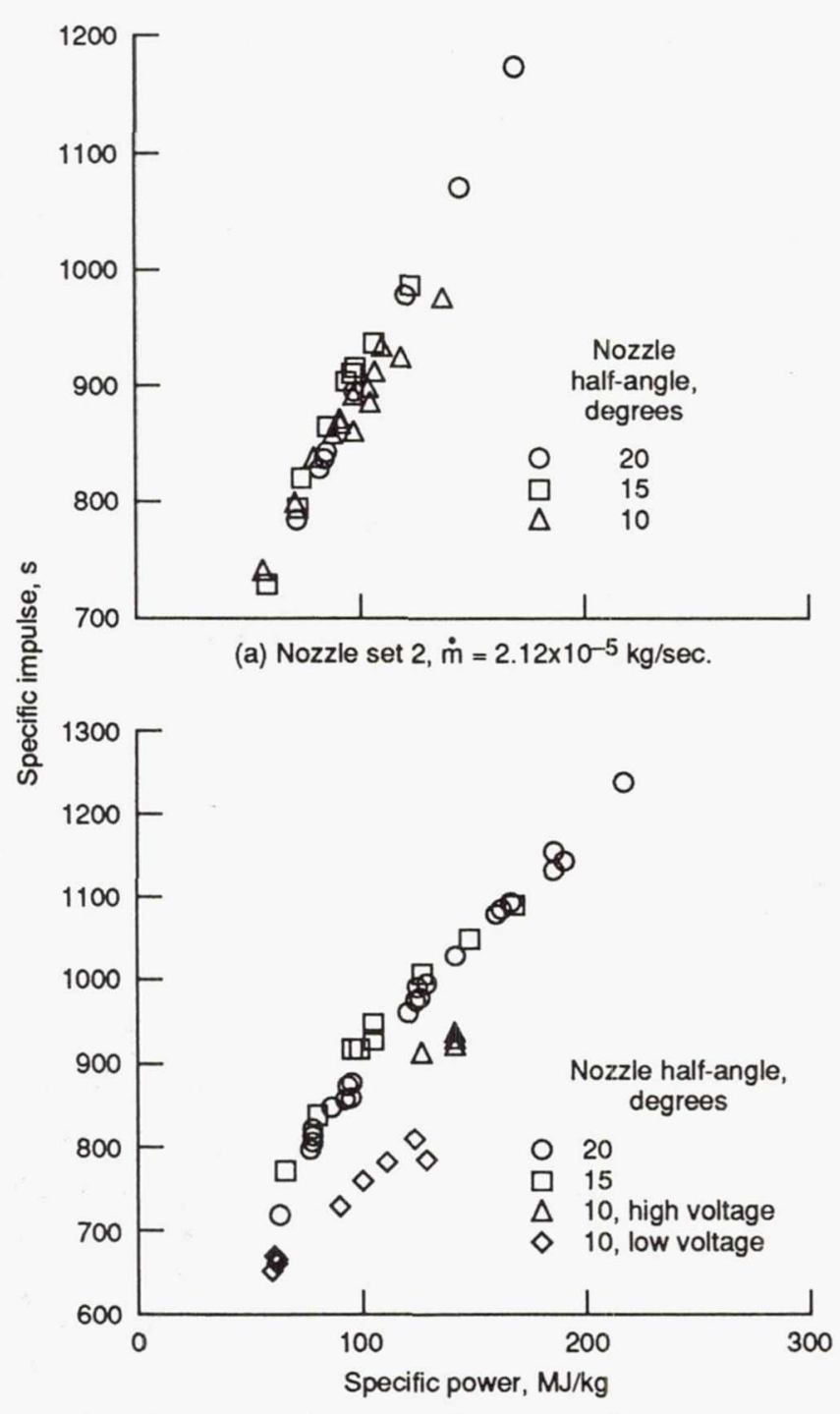

(b) Nozzle set $1, \dot{m}=1.61 \times 10^{-5} \mathrm{~kg} / \mathrm{sec}$.

Figure 5.-Effects of nozzle angle. 


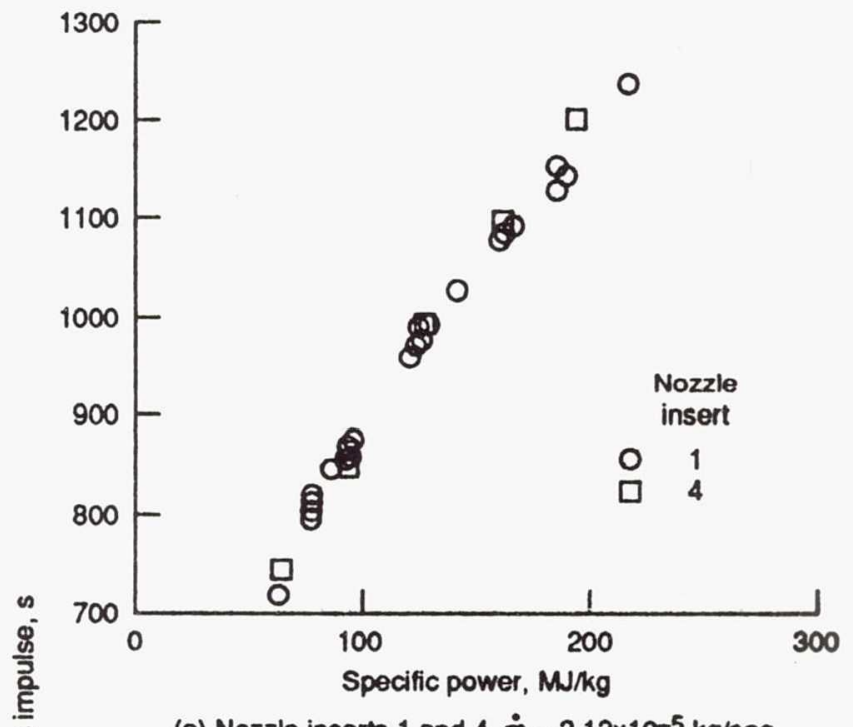

(a) Nozzle inserts 1 and $4, \dot{m}=2.12 \times 10^{-5} \mathrm{~kg} / \mathrm{sec}$.

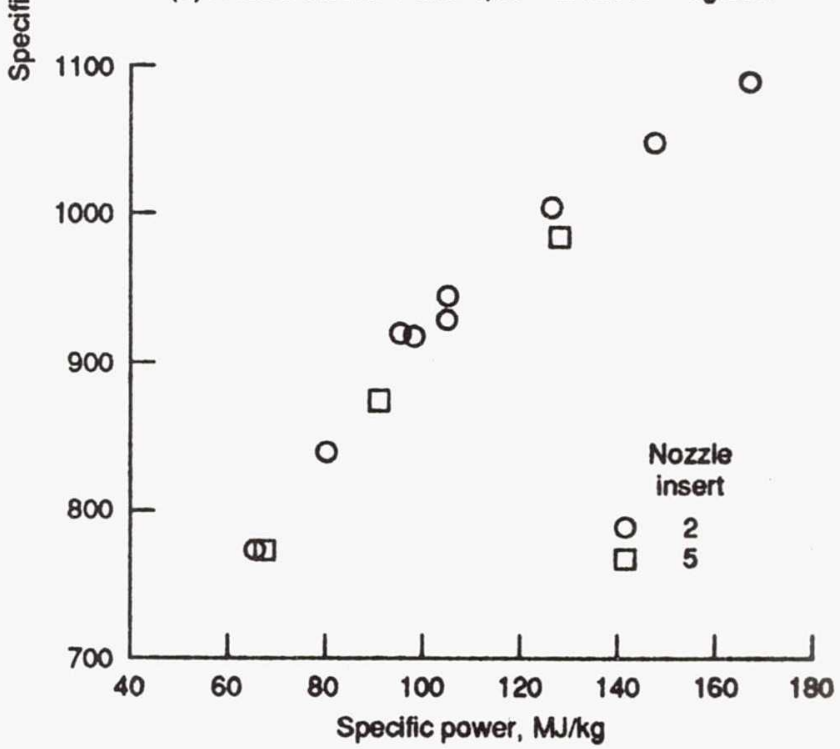

(b) Nozzle inserts 2 and $5, \dot{m}=1.61 \times 10^{-5} \mathrm{~kg} / \mathrm{sec}$.

Figure 6.-Performance comparison between nozzle sets. 


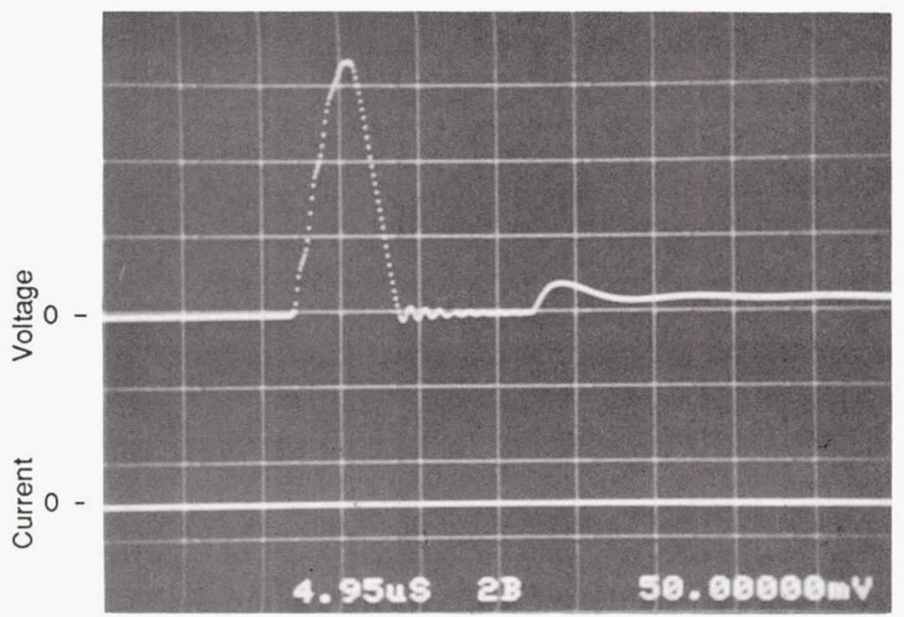

Figure 7.-Typical high voltage starting pulse; 1000 V/div; $4.95 \mu \mathrm{s} / \mathrm{div}$.

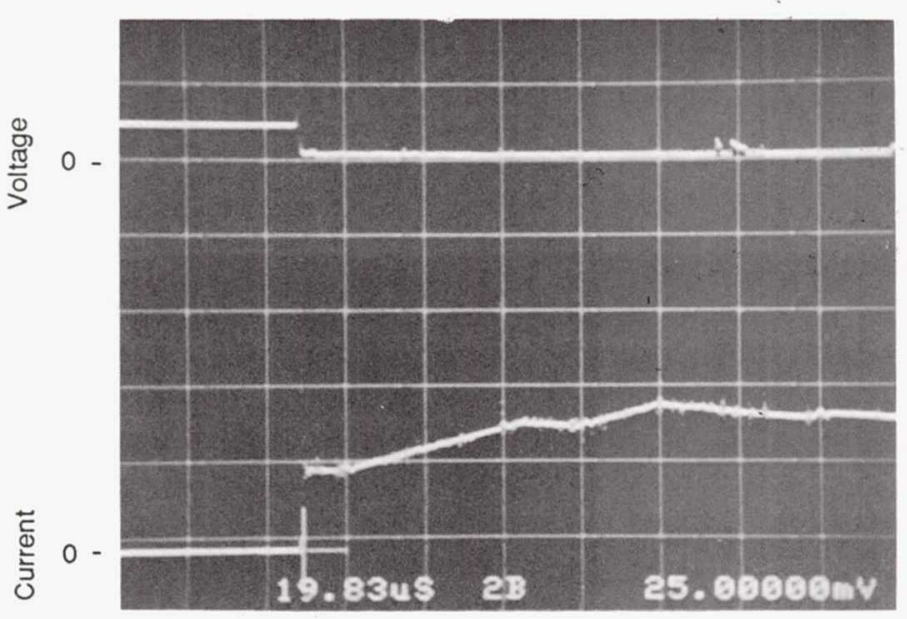

(a) Successful starting attempt.

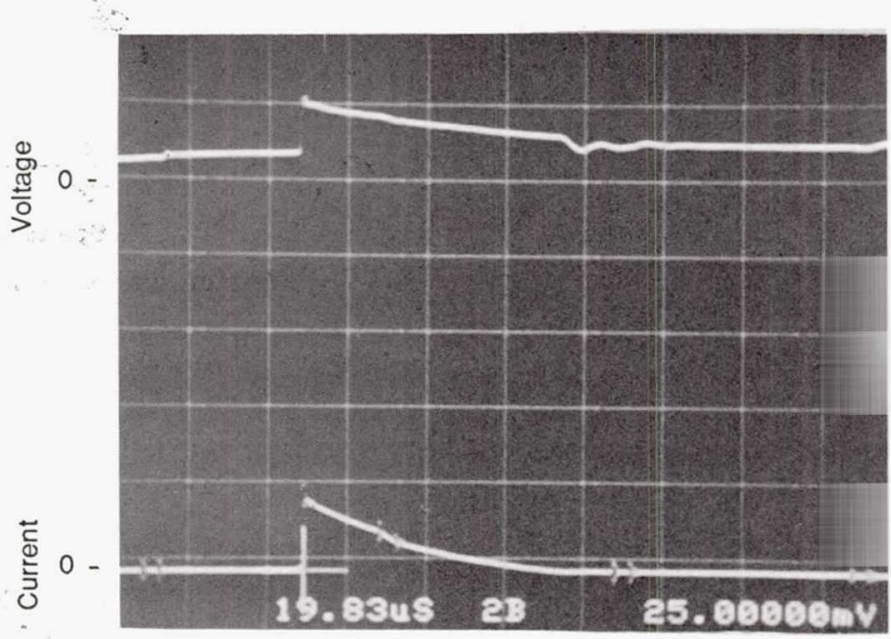

(b) Unsuccessful starting attempt.

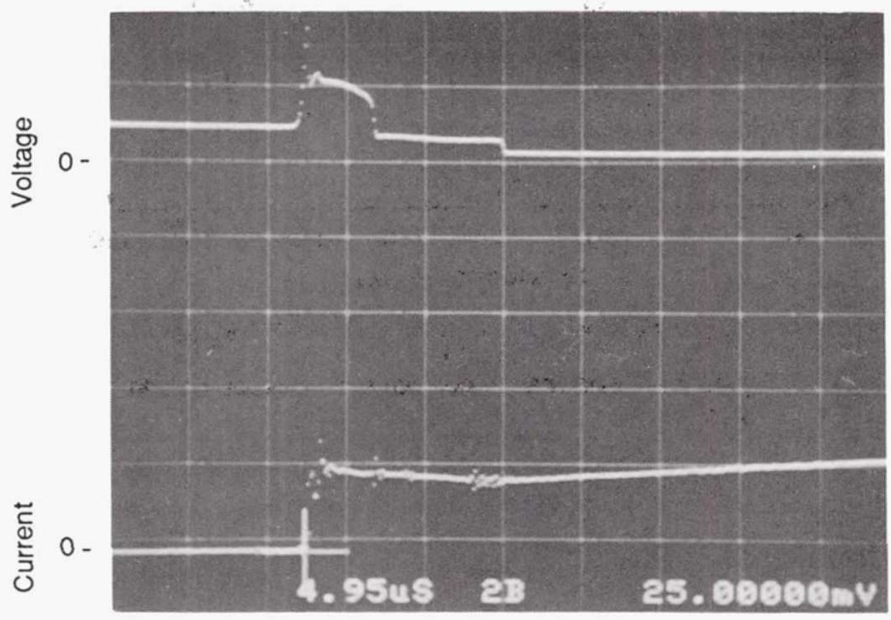

(c) Intermediate case-glow discharge following by ignition.

Figure 8.-Arcjet starting characteristics. Upper trace: voltage - $500 \mathrm{~V} / \mathrm{div}$; lower trace: current - $13.25 \mathrm{~A} / \mathrm{div}$. (a) and (b) $19.83 \mu \mathrm{s} / \mathrm{div}$, (c) $4.95 \mu \mathrm{s} / \mathrm{div}$ 


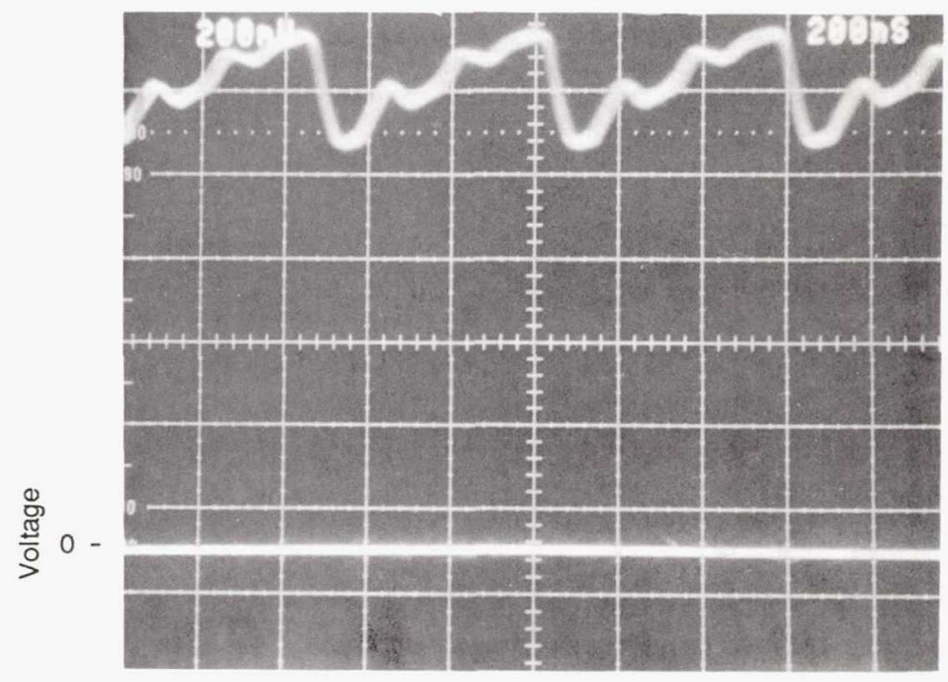

Figure 9.-Typical high frequency voltage fluctuation; $20 \mathrm{~V} /$ div.; 200 ns/div.

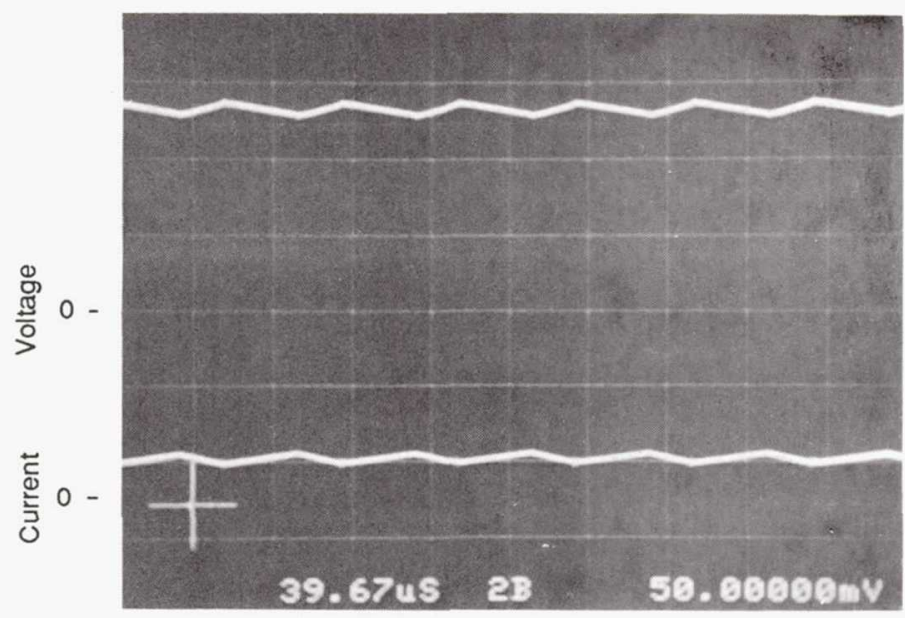

(a) High mode operation.

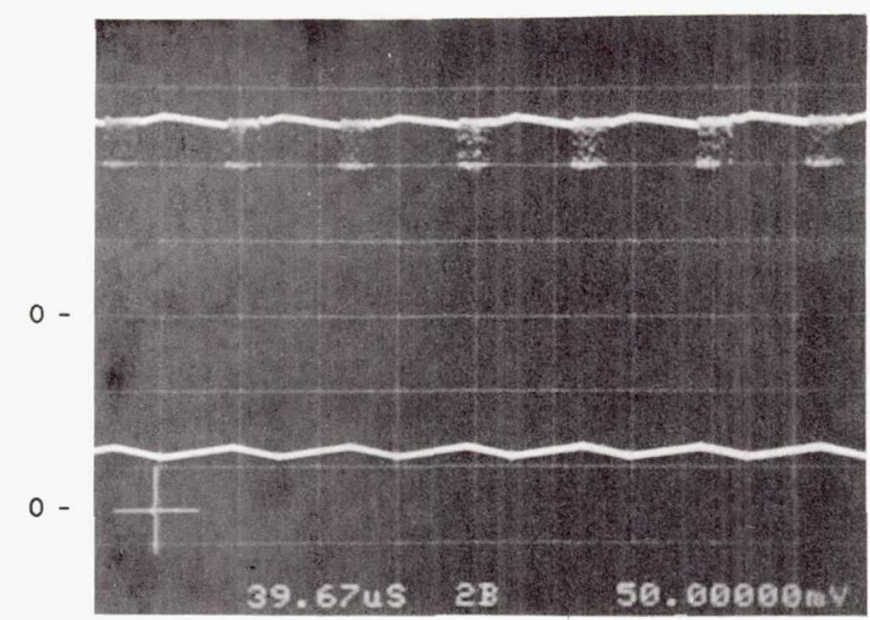

(b) Transition to restrike möde.

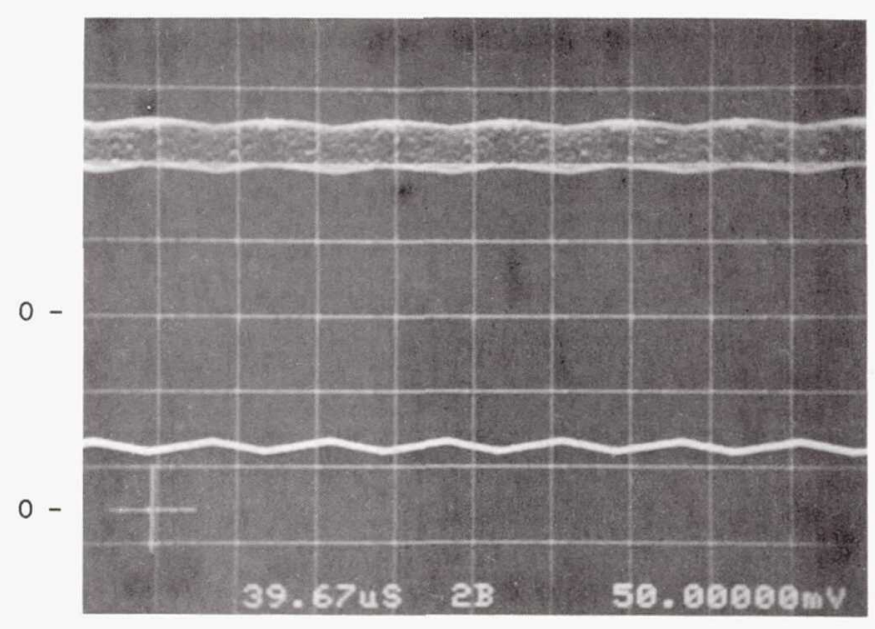

(c) Continuous restrike mode.

Figure 10.-Dynamic arc characteristics. Upper trace: voltage - $50 \mathrm{~V} / \mathrm{div}$; lower trace: current - $26.4 \mathrm{~A} / \mathrm{div} ; 39.67 \mu \mathrm{s} / \mathrm{div}$. 


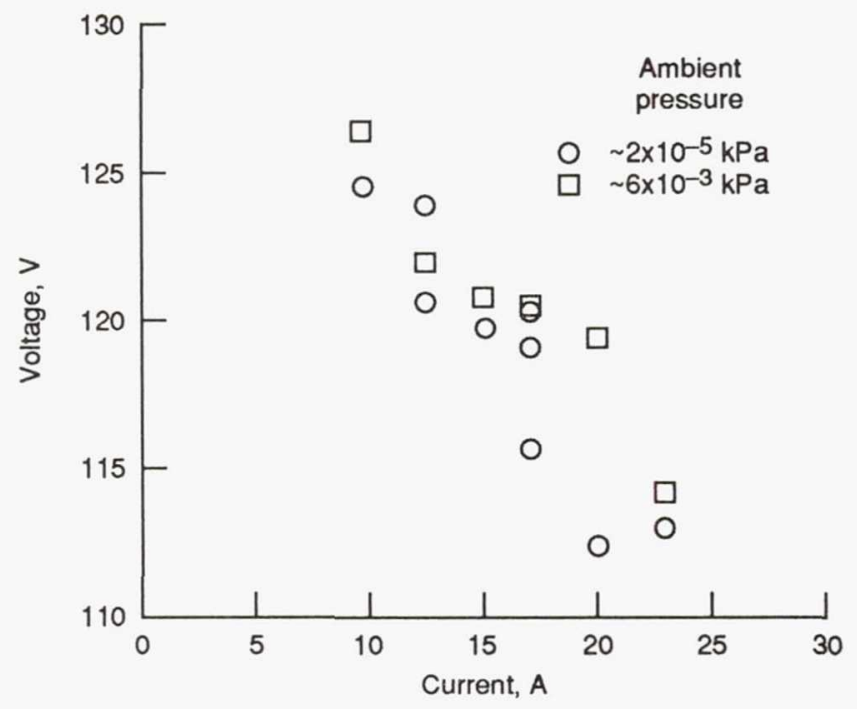

(a) Current/voltage characteristics; nozzle insert 5 , $\dot{m}=2.12 \times 10^{-5} \mathrm{~kg} / \mathrm{sec}$.

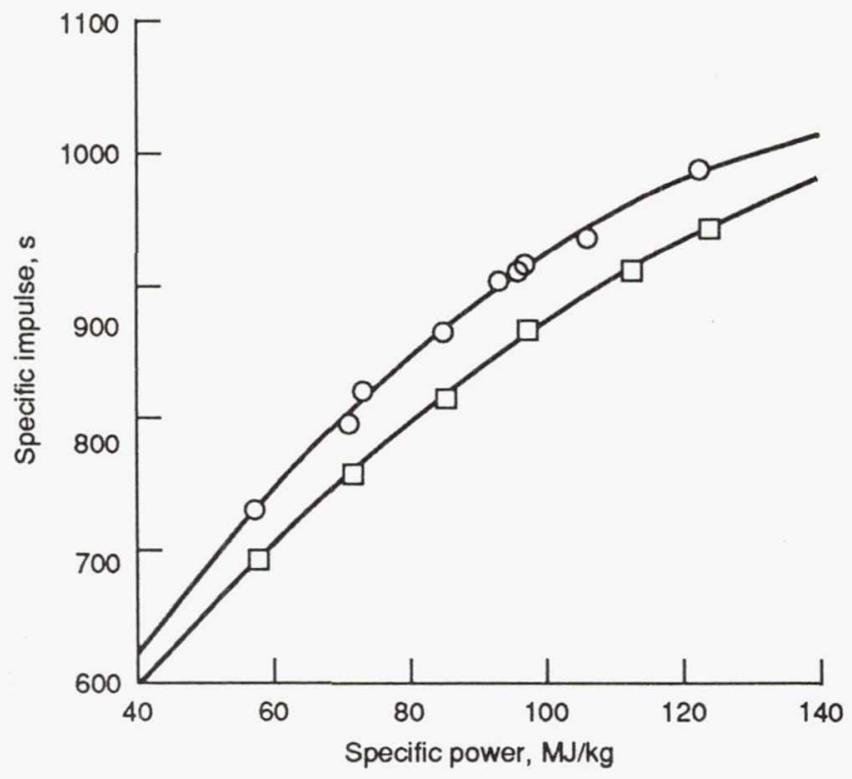

(b) Specific impulse versus specific power; anode insert $5, \dot{m}=2.12 \times 10^{-5} \mathrm{~kg} / \mathrm{sec}$.

Figure 11.-Facility background pressure effects. 


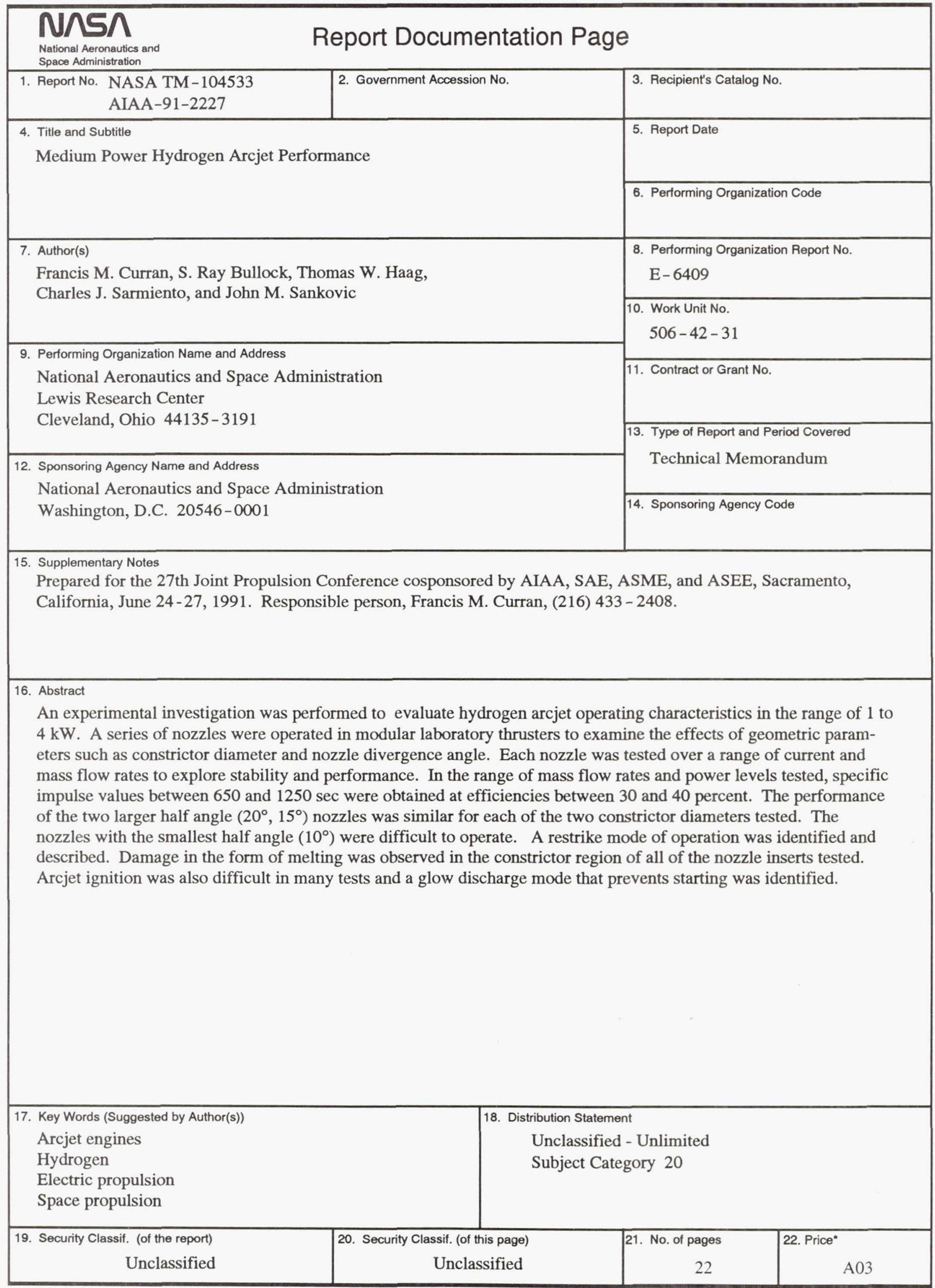

